\title{
Construção e desconstrução das Subprefeituras na cidade de São Paulo no governo Marta Suplicy
}

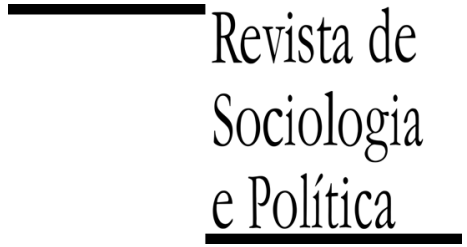

DOI 10.1590/1678-987315235507

\section{Eduardo José Grin}

\section{Resumo}

O objeto da pesquisa é a implantação das Subprefeituras na cidade de São Paulo na gestão petista da prefeita Marta Suplicy (2001/2004). O artigo busca contribuir para um tema carente na Ciência Política brasileira: a descentralização intramunicipal e seus impactos sobre o jogo político e administrativo. Realizou-se uma análise qualitativa em um estudo de caso, empregando process tracing para identificar as condições causais que incidiram na configuração política e administrativa das Subprefeituras. Discute-se como as Subprefeituras serviram para o governo para consolidar sua base de apoio parlamentar, apesar de secundarizar a democracia participativa nas regiões. Analisa-se como o governo enfrentou a resistência das Secretarias municipais temerosas de perder poder para as Subprefeituras. O artigo discute duas hipóteses. A primeira é que o governo recuou do proposto no projeto das Subprefeituras diante da oposição das Secretarias municipais, alimentada pela disputa interna no PT, partido majoritário da coalizão, e seus objetivos de poder nesses órgãos. A descentralização ficou condicionada ao nível de adesão das políticas setoriais. A segunda compreende que o governo abandonou o modelo de Subprefeituras como núcleos locais de poder amparados no controle social, pois essas passaram a servir para ampliar a política de alianças no parlamento, relegando o Orçamento Participativo a uma posição secundária. As hipóteses se confirmaram, pois a explicação causal sugerida se evidenciou na análise empírica. Administrativamente, o alcance limitado das Subprefeituras teve como causa central o temor das Secretarias de perderem poder para as regiões. A descentralização dependeu de como as Secretaria envolveram-se nesse processo. Politicamente, as Subprefeituras foram recursos para o governo ampliar sua coalizão de apoio, sendo essa a explicação causal da prioridade conferida pelo governo à lógica da vereança.

PALAVRAS-CHAVE: subprefeituras; descentralização; coalizões políticas; vereadores; controle social.

Recebido em 27 de Novembro de 2013. Aceito em 26 de Maio de 2014.

\section{Introdução ${ }^{1}$}

${ }^{1}$ Agradecemos aos comentários e sugestões dos pareceristas anônimos da Revista de Sociologia e Política.
$\mathrm{M}$ aquiavel (1983) já lembrava que nada é mais difícil de executar, mais duvidoso de ter êxito ou mais perigoso de manejar do que dar início a uma nova ordem de coisas. Se mudanças institucionais alteram a configuração administrativa e a partilha de poder entre atores políticos, o postulado maquiavélico torna-se ainda mais contundente. Quando o governo petista da prefeita Marta Suplicy (2001-2004) encetou a descentralização político-administrativa no município de São Paulo e implantou as Subprefeituras, essa dificuldade influenciou seu escopo. Na "ordem das coisas", a prática institucionalizada na política municipal de dividir o poder com os vereadores nas regiões para compor a coalizão de governo cobrou seu preço. $\mathrm{O}$ artigo discute como as Subprefeituras gradativamente foram descontruídas em relação ao discurso petista de renovar a política municipal. O governo caminhou em direção a construir sua coalizão de apoio assentada nas bases tradicionais da política municipal de dividir poder com os vereadores nas regiões, e essa prioridade limitou a inovação das Subprefeituras como um modelo de gestão com mais controle social nas regiões.

O artigo analisa como o governo transformou as Subprefeituras no principal estímulo a mediar sua relação com os vereadores do PT e demais partidos, 
visando formar a coalizão política dominante e sua base de apoio parlamentar. Busca-se identificar os atores políticos que, com seus interesses e recursos políticos, acabaram constrangendo a forma e o ritmo da descentralização política e administrativa. Um dos efeitos dessa opção do governo foi secundarizar os mecanismos de democracia participativa e controle social. No plano interno, analisa-se como o governo enfrentou a oposição das Secretarias municipais temerosas de perder poder para as Subprefeituras, fator que também influiu o desenho da descentralização.

O problema a ser analisado está organizado em torno de duas questões. Inicialmente, avaliar se o projeto da descentralização possuía unidade interna no debate governamental. Tal questionamento importa pois, desde o seu início, houve divergências que extrapolaram o aparente consenso existente no PT durante a campanha eleitoral no ano 2000. Importa verificar como a oposição interna das secretarias influiu no desenho da descentralização. Sobretudo, as escolhas políticas do governo frente a esse conflito que ocorreu com as Secretarias municipais, pois as Subprefeituras eram parte de um amplo projeto de reforma administrativa do Estado em nível local.

Em segundo lugar, verificar como as Subprefeituras serviram para o governo consolidar sua coalizão de apoio na Câmara Municipal de modo distinto daquele apresentado na campanha eleitoral. Como a construção da governabilidade no parlamento adquiriu centralidade é importante analisar como as Subprefeituras serviram de recurso político do poder Executivo na barganha com os vereadores e as razões que levaram o governo a alterar sua compreensão do papel dos parlamentares na gestão local. Sobretudo, porque essa prioridade assumida pelo Executivo reduziu a relevância política que poderia ter os mecanismos de democracia participativa na gestão territorial.

Esse problema de pesquisa embasa duas hipóteses de trabalho. A primeira é que o governo recuou das intenções iniciais do projeto das Subprefeituras em face da resistência das Secretarias municipais, alimentada pela disputa interna no PT, partido majoritário da coalizão, e seus objetivos de poder nesses órgãos. A implantação das Subprefeituras ficou condicionada ao nível de adesão de cada política setorial, o que gerou problemas para integrar as ações nos territórios, tal como previsto no projeto. Os arranjos políticos e administrativos entre as regiões e as Secretarias municipais, decorrentes dos atores políticos, seus interesses e recursos políticos, prevaleceram sobre um formato unificado de Subprefeituras.

A segunda compreende que o governo abandonou o modelo de Subprefeituras como núcleos locais de poder amparados no controle social diante da prioridade assumida pela "lógica da vereança" nos territórios. As Subprefeituras serviram para ampliar a política de alianças e a descentralização aliou-se à prática recorrente na cidade de São Paulo de partilhar o poder cooptando vereadores, mesmo sendo criticada pelo PT como método malufista ${ }^{2}$ para cons-

2 Trata-se de uma referência ao Prefeito de São Paulo Paulo Maluf (1993-1996) e seus métodos de cooptação de vereadores de forma fisiológica.

\footnotetext{
${ }^{3}$ Encontrou-se apenas a dissertação de Lameirão (2007) e o artigo de Boschi (1999), embora este último associe descentralização com democracia participativa.
} truir maiorias. Como efeito dessa prioridade, o governo relegou o Orçamento Participativo e os movimentos sociais uma posição secundária na coalizão política dominante.

O artigo também busca contribuir para um tema carente na Ciência Política brasileira: a descentralização intramunicipal, sobretudo nas grandes cidades, e seus impactos no jogo político e administrativo local ${ }^{3}$. Especialmente, identificar os atores políticos que, com seus interesses e recursos políticos, influenciam os processos de reforma do poder público municipal. A literatura tem analisado a descentralização no contexto federativo e de relações intergovernamentais (Melo 1996; Kugelmas \& Sola 1999; Arretche 1999; 2002; Abrucio 2005; Almeida s.d. 2005; Falleti 2006), mas não como política de gestão das cidades. $\mathrm{O}$ estudo do tema pode ser ampliado, de forma comparada, 
pois ao menos as seguintes metrópoles brasileiras têm adotado a descentralização/desconcentração territorial (Tabela 1).

A primeira seção apresenta a metodologia utilizada, seus procedimentos empíricos e técnicas de análise. Segue-se com as referências teóricas utilizadas: a visão pluralista sobre o papel dos governos municipais para construir suas coalizões de apoio no parlamento. A segunda parte se apoia no institucionalismo histórico e o argumento de que as trajetórias prévias em arenas de políticas podem limitar o alcance das inovações governamentais. A terceira parte analisa o debate no interior do governo petista para implantar as Subprefeituras, buscando evidenciar como ocorreu a desconstrução do modelo proposto. Na conclusão, coteja-se a análise do caso com suas hipóteses e referências teóricas, visando explicar os porquês das opções políticas adotadas pelo governo Marta Suplicy em relação as Subprefeituras.

\section{Procedimentos metodológicos}

A análise qualitativa, segundo Ragin (1987), orienta-se para casos historicamente localizados que possam ser examinados a partir de uma configuração empírica de condições e causas contextuais. Esse tipo de análise é sensível à complexidade e especificidade histórica e seus resultados embasam esquemas conceituais para compreender uma totalidade conjuntural onde há ação humana em questões de natureza social e política. Segundo Ragin (idem, p. 3), casos são configurações interpretadas para "explicar resultados históricos específicos, o conjunto de resultados comparáveis ou os processos escolhidos a serem estudados por causa de seu significado para os arranjos institucionais ou para a vida social em geral". Assim, pode-se encontrar condições causais que inserem uma análise individual numa configuração mais ampla. O estudo de casos permite reunir evidências sensíveis à cronologia dos fatos para melhor conhecer a trajetória de eventos significativos e as decorrentes associações entre causa e efeito, desde que orientados por categorias teóricas.

A pesquisa também utilizou a metodologia do process tracing, conforme Gerring (2007): evidências contextuais fazem sentido se podem adequar-se em um universo de relações causais compreensíveis, ordenadas e "narrativizadas", desde que apoiadas em suposições teóricas. Para Tilly (1983), na análise de casos, o ponto de partida é especificar para quais unidades o exame do investigador se dirige. Mas deve-se evitar análises particularistas que não permitem testar a validade de pressupostos teóricos gerais. É difícil avaliar o impacto dos casos sem se analisar os atores políticos e suas crenças no interior de históricas

Tabela 1 - Descentralização/desconcentração administrativa em metrópoles brasileiras

\begin{tabular}{lll}
\hline Localidade & Ano & Nome \\
\hline São Paulo & 1965 & Administrações Regionais \\
& 2002 & Subprefeituras \\
Salvador & 1983 & Administrações Regionais \\
Belo Horizonte & 1983 & Administrações Regionais \\
Curitiba & 1986 & Administrações Regionais \\
Vitória & 1986 & Gerências Regionais \\
Rio de Janeiro & 1993 & Subprefeituras \\
Fortaleza & 1997 & Secretarias Executivas Regionais \\
João Pessoa & 2008 & Subprefeituras \\
\hline
\end{tabular}

Fonte: $\mathrm{O}$ autor. 
"circunstâncias estruturais". A generalização analítica deve partir de unidades sociais específicas, e dos atores políticos que atuam nesse contexto, sempre considerando um "na medida em que" certos fatores estão presentes para se gerar conclusões mais amplas. Como estudos de caso realizam análises "genuinamente históricas" e assumem o tempo e o lugar em que uma estrutura ou processo faz diferença, e a sequência de eventos influencia os resultados contextuais, requer-se investigação sistemática em vez de se produzir sínteses imediatas e pouco embasadas.

Foram realizadas sete entrevistas semiestruturadas entre fevereiro e agosto de 2010 (quatro na Subprefeitura de Capela do Socorro e três na Subprefeitura da Freguesia do Ó) com os Subprefeitos e coordenadores setoriais, pois esses possuem uma visão política sobre a descentralização. No universo das 31 Subprefeituras, as duas regiões representam duas variantes opostas de partilha de poder, tal como Gerring (2007) concebe essa opção de diverse-case method para analisar o mesmo objeto. Para Gerring (idem, p.99), "diversity may thus refer to a range of variation on $\mathrm{X} 1$ or $\mathrm{Y}$, or to a particular combination of causal factors (with or without a consideration of the outcome). In each instance, the goal of case selection is to capture the full range of variation along the dimension(s) of interest". Uma região manteve a hegemonia do PT e outra cedeu espaço para um adversário político proveniente de um partido "tradicional" (PPB, hoje PP, partido de Paulo Maluf) para obter apoio na Câmara Municipal. Considerando a escolha dos casos, eles distinguem-se na variável dependente (Y), pois em um a descentralização (X/variável independente) não gerou mudanças (Capela do Socorro) e em outro alterou completamente o desenho político e administrativo (Freguesia do Ó). A escolha dos casos ocorreu por sua diversidade representar a ampla variação que as 31 Subprefeituras (a população estudada) geraram em sua composição política, mas pautada pelas mesmas condições causais que foi a política de alianças para construir a coalizão política dominante.

No governo "central", entrevistaram-se três atores políticos com incidência estratégica sobre a descentralização: Chefe de Gabinete da Secretaria de Governo Municipal (responsável pela negociação com os vereadores), Coordenador Municipal do Orçamento Participativo (respondia pelo tema da participação popular) e a Secretária Municipal de Assistência Social, ex-Secretária das Administrações Regionais da gestão petista em 1989-1992 (possuía o histórico da descentralização). A pesquisa realizou uma análise de documentos (leis, decretos e portarias) disponíveis no banco de dados da Câmara Municipal. Finalmente, analisaram-se fontes secundárias e textos governamentais, além do estudo hemerotécnico em matérias da Folha de São Paulo e O Estado de São Paulo entre 2001 e 2005.

\section{Atores políticos e suas estratégias em contextos de mudança}

Em termos teóricos, o artigo analisa como atores políticos agem em contextos de mudança institucional. Para tratar dessa questão, discute-se o pluralismo e a forma como concebe a ação dos atores políticos. Segue-se abordando o institucionalismo histórico e o argumento de que as instituições, políticas e suas regras constrangem ação dos atores políticos, especialmente quando governos propõem inovações nas políticas.

\section{III.1. A política municipal e a ação dos atores políticos}

Conforme o pluralismo, nos "temas-chave" (issue areas) da política configuram-se arenas decisórias com diferentes atores, interesses e recursos políticos para gerar coalizões de políticas que distribuem poder e permitem explicar as 
decisões governamentais. O governo municipal é um ator político que dispõe de recursos para decidir sobre políticas (Dahl 1958; 1989; Polsby 1960). Os grupos políticos à frente do Executivo dispõem de capacidades desiguais para incidir no jogo político, sendo o controle dos empregos públicos uma "arma política regular". O mais importante uso político desses empregos é criar uma Câmara de Vereadores flexível. Quando o governo precisa de votos, não reluta em estender seus favores ao parlamento com a política de "cenoura e porrete" (carrot and stick): mas mesmo votando a favor do governo os vereadores o fazem temendo perder seus benefícios que são sempre relembrados pelo porta-voz do governo nas votações cruciais (Dahl 1989). Esses recursos políticos forjam acordos mais estáveis, pois a política não garante alianças duradouras (Dahl 1989; 1961; Polsby 1960).

Conforme Dahl (1989, p.126), existem três tarefas inter-relacionadas para o governo formular e executar políticas: $(i)$ definir a direção da política enfatiza o que será realizado e quanto de recurso será investido; (ii) desenvolver propostas e negociar acordos em torno delas; (iii) realizar as políticas quando obtém suficiente acordo na negociação. Ao explicitar seus objetivos o governo cria uma "área em questão" que permite aos atores políticos adaptarem suas estratégias. As alianças que se formam para sustentar tal prioridade podem ser heterogêneas e envolver "estranhas coalizões como nunca houve". Mas ao atender tantos interesses, o governo está consciente dos limites das políticas que inicia, pois cada segmento é o que Dahl (1989) chama de "pequenas soberanias": áreas controladas por diferentes líderes com seus interesses, o que dificulta coordenar as políticas.

Para construir um padrão de coordenação e de liderança, o prefeito atua como a interseção das negociações para integrar políticas e atores políticos. Mas embora o prefeito possa ser influente, esse arranjo não é hierárquico, pois tais coalizões não são monolíticas, enfrentam contestação interna sobre sua autoridade, podem ser afetadas por ambíguas relações de influência e estão sujeitas à barganha dos atores políticos. Para reduzir tais atritos o governo faz indicações e constrói lealdades em áreas onde sua liderança é mais fraca (idem). Por isso, o governo nem sempre confere inequívoco suporte aos membros de sua coalizão original, pois quando e como apoiá-los depende de objetivos políticos maiores.

Segundo Dahl (idem), o governo municipal também pode "deliberadamente criar" a participação dos cidadãos nos "negócios públicos" para apoiar suas políticas e ampliar sua legitimidade. Mas, em regra, tais instrumentos são uma "fachada democrática", pois as decisões centrais provêm do governo ou da barganha que realiza com o Legislativo. Logo, para além da superfície da participação, deve-se identificar as decisões sobre temas de interesse e quem as inicia como forma de avaliar o peso real dos cidadãos nas decisões governamentais. Com esse "ritual democrático" o governo busca abrir canais de influência junto a vários atores políticos que deseja apoiar, cooptar ou neutralizar, além de apresentar propostas como uma iniciativa não partidária para reforçar que o poder e a responsabilidade são compartilhados com a sociedade.

Para Mollenkopf (1994), a "coalizão política dominante" é chave para conhecer-se os atores políticos e as estratégias utilizadas pelo governo para conformar sua base de apoio. O desafio é converter o sucesso eleitoral em sólida coalizão de governo. Esta, "para permanecer dominante [...] deve ser capaz de administrar as tensões que inevitavelmente surgem das diferenças de interesse entre sua base eleitoral e seus aliados no governo" (idem, p.5). Embora "interesses contraditórios" denotem a diversidade de atores, com tal coalizão o Executivo divide oponentes e secundariza velhas clivagens políticas ao refazer alianças em torno de uma centralidade de poder encabeçada pelo prefeito. A coalizão dominante é uma aliança tática entre diferentes interesses que podem 
ganhar eleições e assegurar a cooperação com outros centros de poder para governar. Esse processo, com os recursos políticos que o governo detém, cimenta a unidade entre grupos políticos contraditórios. Daí a importância de saber como se constitui esse arranjo político de interesses nem sempre coincidentes, a partir das "regras" que organizam a competição política municipal (idem).

Na coalizão dominante se "acomodam" distintos interesses e estratégias dos atores políticos em relação ao governo municipal. Dentre esses, Mollenkopf (idem) destaca o "setor público produtor de interesses" que compreende atores como os partidos políticos e os executivos eleitos e/ou indicados para exercer funções governamentais. Para Mollenkopf (idem, p.39), os arranjos políticos favorecem tendências conservadoras na formação e atuação da coalizão dominante ao manterem padrões prevalecentes de distribuir empregos, contratos e outros tipos de benefícios. Como esse processo é centralizado no gabinete do Prefeito, ele revela as escolhas políticas para tornar-se dominante. Daí a relevância de analisar-se os mecanismos de ação governamental para construir sua coalizão política dominante.

\section{III.2. Instituições políticas e atores políticos}

Para Skocpol (2002), a análise das ações do Estado deve identificar políticas específicas para conhecer os atores beneficiados e desfavorecidos. Isso remete às estratégias e recursos políticos utilizados pelo Estado e os atores. Segundo Lowi (1964), “arenas de poder” são estruturas institucionais de políticas, cujas normas de funcionamento podem ser mais relevantes na decisão sobre políticas do que apenas considerar a ação dos atores. Se o poder é a capacidade de os atores participarem na produção de políticas, importa analisar as arenas em que se organizam essas relações e a trajetória de decisões do mesmo tipo. Para esta pesquisa interessa o que Lowi chama de "arena política distributiva": não possuem normas gerais e têm no parlamento seu lócus decisional para gerar acomodações de interesses que ampliam o acesso dos atores políticos às ações de governo. As coalizões que advêm desse processo "devem ser construídas para passar a legislação e "fazer políticas"” (idem, p.693). Nesse tipo de arena, o único compromisso comum dos atores políticos é facilitar o seu acesso aos benefícios públicos. O governo atua como o "negociador" das concessões junto ao parlamento como local privilegiado dessa política. Nas cidades, "esta é a arena onde a máquina da dominação continua, se tal máquina estiver no controle em primeiro lugar". Promove-se a política de cooptação antes que o compromisso, pois ao atender um grande leque de atores o governo visa desarticular a oposição e estabilizar sua coalizão (idem, p.713).

Conforme Skocpol, “estruturas de administração pública e organizações de partidos políticos percorrem um longo caminho para ‘selecionar' os tipos de questões políticas que entrarão (ou serão mantidas fora) da ‘agenda política' da sociedade" (Skocpol 2002, p. 25; grifos no original). Portanto, podem coincidir os interesses políticos do governo e dos partidos em torno de questões "específicas" de natureza distributiva. E uma vez mobilizados os interesses de um grupo político em uma dada direção, esses tendem a manter suas demandas com as mesmas linhas de ação. Os atores políticos realizam seu cálculo político considerando os procedimentos de cooperação institucionalizados que presidem as suas mútuas relações, geralmente apoiando-se em instituições e práticas políticas que historicamente mediam seus vínculos.

Nesse sentido, para Weir (1992), a “inovação limitada de políticas” instala arranjos institucionais que criam oportunidades de mudança, mas que possuem limites. Com o passar do tempo, as ideias perdem influência, pois o desenho institucional do Estado pode estreitar o curso da inovação se os atores políticos 
buscam manter seus interesses ao formarem coalizões políticas. Assim, importa compreender como os grupos constroem seus interesses nas políticas e como atuam nos conflitos que surgem no interior das instituições, sobretudo quando se busca reorganizar o Estado. Considerando a "dependência da trajetória", decisões em um ponto no tempo podem restringir as possibilidades das políticas se afastarem de rotas ao longo do qual atores, ideias, interesses e instituições têm se adaptado (idem, p.192).

Conforme King (1992), as ideias são traduzidas em linguagem apropriada à decisão política e geralmente resultam em metamorfose das noções originais, cabendo aos partidos um papel crucial nesta "tradução". Um dos efeitos é a "inovação limitada" das políticas devido às características prévias do contexto institucional aceitas pelos atores políticos. O sistema político inova, mas há "dificuldades de estender-se os limites enraizados nas políticas existentes" (Weir 1992, p.211). Para Weir (idem, p.194), na formação de alianças políticas, um fator que determina como os grupos definem seus interesses é a organização das instituições políticas. Em particular, o sistema de partidos e as legislaturas que incidem sobre a agregação de interesses e na forma como os atores políticos produzem políticas.

Reformas institucionais podem ser pré-requisitos para institucionalizar novas políticas e demandam coalizões políticas que devem ser analisadas para verificar por que alguns atores políticos são favorecidos em detrimento de outros. Ao mesmo tempo, esse processo reposiciona os atores políticos como decorrência da revisão que sofre a política em questão. Assim, o governo pode retrabalhar uma política para torná-la aceitável junto a alguns atores políticos e, ao recuar de suas intenções manifestas, reduz o apoio em outras arenas de políticas. A maneira de tratar uma política pode gerar problemas de interação político-administrativa e intensificar as dificuldades de relacionamento entre unidades do governo, pois pode ser que certas políticas incidam sobre as relações historicamente constituídas entre seus órgãos (idem).

Para Immergut (1992) e Thelen e Steinmo (1992), o lugar dos atores políticos no desenho institucional pode beneficiar ou impedir que seus interesses se traduzam em poder concreto. Mudanças no jogo político podem afetar o funcionamento institucional e gerar distintos padrões de comportamentos dos atores políticos em uma mesma arena de políticas. Segundo March e Olsen (1984), o partido vencedor nas eleições pode ampliar os "direitos" de participação a alguns atores políticos, o que altera a distribuição de poder e o contexto institucional, mas pode comprometer o curso de uma política se outros atores forem menos considerados. Quando adotadas, políticas "são inseridas em instituições, mas se afetam as aspirações dos atores políticos podem alterar seus comportamento" (idem, p.745).

Segundo Thelen e Steinmo (1992), a análise institucional deve desnudar os interesses e relações de poder que incidem sobre a trajetória e as arenas de políticas. Esses são fatores de "dinamismo institucional" que podem afetar o jogo político, geralmente quando velhas instituições são postas a serviço de novos fins. Por isso, para Thelen e Steinmo (idem, p.9), "onde grupos têm múltiplos, frequentemente conflitantes interesses, é necessário examinar o processo político em que particulares coalizões são formadas". Decerto que as manobras estratégicas dos atores políticos decorrentes da política de governo provocaram conflitos de interesse que influíram no contexto institucional das Subprefeituras e produziram efeitos que limitaram seu alcance inovador, como se aborda a seguir. 


\section{A concepção das subprefeituras no governo Marta Suplicy}

Desde a década de 1960 já existiam as Administrações Regionais (ARs) que organizacionalmente desconcentravam serviços e politicamente eram funcionais para os governos comporem sua base de apoio parlamentar, sobretudo após 1985. Tais antecedentes da descentralização influíram na política adotada pelo governo petista, especialmente a relação com os vereadores, como será visto. Se as Subprefeituras eram uma novidade, também carregaram a herança da lógica prevalecente na política municipal que servia para orientar o cálculo político dos governos, pois as regiões mantiveram sua característica de ser um poderoso recurso político na construção das coalizões governamentais.

As Subprefeituras foram a principal mudança na administração pública municipal em São Paulo desde a criação, em 1965, das ARs. As Subprefeituras basearam-se no projeto da gestão petista de Luiza Erundina (1989-1992), conforme: documentos governamentais (PMSP 1991a; 1991b), livros editados pela Prefeitura (PMSP 1992a; 1992b) elaborações teóricas de atores políticos governamentais (Jacobi 1990; 1991; Sader 1992) e artigos acadêmicos (Keinert 1993; Martins 1997). Na campanha eleitoral, em 2000, segundo o programa da Coligação Muda São Paulo (PT-PCdoB), as Subprefeituras deveriam democratizar o poder político, reconstruir capacidades estatais e ampliar a governabilidade na gestão municipal. Por isso importa apresentar as teses gerais do modelo que o PT e o governo propunham.

As Subprefeituras seriam "centros regionais com poder de decisão" e a gestão local seria mais democrática e com maior capacidade institucional (Sposati 2001; Garibe 2004; 2006; Capucci 2004). A gestão das políticas públicas se apoiaria nos Conselhos de Representantes eleitos localmente para exercer o controle sobre as Subprefeituras e a Câmara de Vereadores. As Subprefeituras implantariam essa política por estarem mais próximas do cidadão, além de auxiliarem o PT e a bancada governista a enfrentar a corrupção e o autoritarismo do parlamento. Os fóruns de controle social seriam a base da governabilidade e o diálogo direto com a população reduziria a influência clientelista dos vereadores que historicamente "capturavam" as ARs (Sposati 2002; Santos \& Barreta 2004).

As políticas públicas locais seriam executadas de forma integrada para a gestão municipal pautar-se por demandas locais e não mais em ações centralizadas e setoriais (Fernandez \& Mendes 2003; Finatec 2004; Martins 2006; Donato 2006). Com a inter-setorialidade e a transversalidade das políticas, as Subprefeituras atenderiam melhor as demandas oriundas da participação popular, qualificariam a oferta de serviços públicos e ampliaria sua racionalidade administrativa (Capucci 2004; Garibe 2004; 2006; Donato 2006). Ademais, a descentralização, associada à democracia participativa, direcionaria a ação pública em favor da sociedade. Mas, essa visão normativa não gerou uma política democrática "empurrando" a ação do governo, e tampouco a ação intersetorial foi o eixo organizativo das Subprefeituras, como a seguir se discute.

\section{Subprefeituras: a descentralização errática}

O debate governamental teve três momentos-chave sobre o projeto das Subprefeituras: (i) em 2001: o modelo da descentralização configurado no primeiro projeto de lei; (ii) em 2002: a implantação dos "Governos Locais", a aprovação da lei das Subprefeituras e o debate sobre a reforma administrativa do nível central; (iii) os anos de 2003 e 2004: a implantação administrativa das Subprefeituras e as dificuldades para a descentralização das políticas setoriais. A seguir será discutido como a descentralização foi sendo desconstruída pela 
ação das políticas governamentais e resultou na sua implantação errática nos territórios.

\section{V.1. O ano de 2001 e os impasses iniciais em direção às Subprefeituras}

Como um eixo programático, a descentralização se inseriu na agenda da gestão Marta Suplicy desde seu início. O Decreto n. 40227 (1 jan. 2001) alterou o nome da Secretaria das Administrações Regionais para Secretaria de Implementação das Subprefeituras (SIS). Mas nesse ano já surgiram dificuldades dentro do governo para produzir-se um acordo sobre o modelo de Subprefeituras. Segundo o Chefe de Gabinete da Secretaria de Governo (Entrevista ao autor, 12 fev. 2010), a divergência central era o número de Subprefeituras, que combinava-se com a existência ou não de quadros técnicos capazes. Por trás dessa intenção, avaliava-se que o número de Subprefeituras deveria reproduzir e/ou ser próximo à distribuição regional do PT para apoiar os movimentos sociais e o partido local, em linha com o argumento de Mollenkopf (1994) acerca do "setor público produtor de interesses".

Mas havia outro argumento no debate interno: limitar as Subprefeituras a 500 mil habitantes, e ampliar o seu número, dividiria melhor o orçamento. Essa posição, que foi vitoriosa, entendia que assim seria possível construir o poder local e descentralizar políticas para o governo qualificar o atendimento às necessidades regionais. Para a tese derrotada, a descentralização era um problema, pois inexistiam quadros técnicos para implantar as Subprefeituras. Essas deveriam ser em menor número para não afetar a qualidade técnica da descentralização e a coordenação governamental. Tal posição era apoiada, por exemplo, pelas secretarias de educação, cultura e finanças, temerosas de perder controle político para as regiões. Por trás desses argumentos de racionalidade administrativa havia o receio da perda de poder, como será visto adiante, o que influiu no caráter inovador do projeto.

A posição de implantar 31 Subprefeituras predominou, mas não houve consenso em torno do modelo de unidades territoriais descentralizadas com autonomia política e administrativa. Isto porque Subprefeituras passariam a responder por uma gama de políticas públicas regionalizadas, o que reduziria atribuições das secretarias. Quando a descentralização começou a passar do discurso à ação evidenciaram-se as divisões internas sobre a sua forma e o seu alcance, devido ao surgimento de distintos interesses e estratégias dos atores políticos governamentais. Até o final de 2001, não havia uma proposta clara sobre como administrativamente organizar a descentralização, pois segundo King (1992), ideias mudam para serem traduzidas em linguagem adequada à decisão política e geralmente alteram as noções originais.

É possível que o governo não quisesse explicitar a magnitude da descentralização para a Câmara Municipal, já que, em 2001, sua base parlamentar era minoritária. Já os vereadores queriam manter influência nos territórios. Assim, é pouco provável que aprovassem uma lei autorizando o Executivo a implantar as Subprefeituras temendo não mais indicarem pessoas de suas bases eleitorais para os cargos locais. Muitos parlamentares recordavam da gestão Erundina, quando as ARs foram distribuídas entre os diretórios zonais do PT (Teixeira 2004). A defesa desse modelo por membros do governo, associado ao discurso do controle social, fazia os vereadores de outros partidos recearem sobre sua influência política nas ARs. Esses atores buscavam impedir, conforme Immergut (1992) e Thelen e Steinmo (1992), que seus interesses fossem afetados na nova divisão de poder territorial.

A dificuldade de o governo construir uma maioria de apoio, associada ao receio de perder a votação e não implantar as Subprefeituras, como ocorreu na 
gestão Erundina, adiou a tramitação dessa matéria. Mas os vereadores sabiam que o governo teria que negociar para obter votos favoráveis para essa proposta. Some-se a isso a disputa por cargos entre vereadores da base governista e o medo de que, com as Subprefeituras, surgissem líderes que reduzissem sua influência local. O projeto de lei foi apresentado em setembro de 2001 e aprovado em julho de 2002 também por falta de acordo na coalizão governista e no PT. Especialmente vereadores de fora da coalizão de governo sabiam que as Subprefeituras estavam na "agenda política" do governo e da sociedade (Skocpol, 2002). Também sabiam que seus votos eram necessários, para forçar um processo de cooperação com o Executivo municipal nessa issue area.

\section{V.2. O ano de 2002: do discurso da descentralização à realidade da política municipal}

O ano de 2002 teve duas etapas centrais: (i) em março, a implantação dos Governos Locais visando preparar a transição político-administrativa às Subprefeituras; (ii) em julho, a aprovação da Lei n. 13 399/2002 que criou as 31 Subprefeituras e propiciou organizá-las.

Os "Governos Locais" foram reativados (Decreto n. 41 813/2002) como fóruns vinculados às ARs, constituídos por técnicos das Secretarias para produzir ações inter-setoriais. O Executivo entendia que se criariam as bases organizacionais para facilitar a transição às Subprefeituras, apesar do poder decisório manter-se nas Secretarias. Mas a formalização das Subprefeituras não aprofundou essa lógica descentralizadora. Após julho de 2002, quando o enfoque passou a ser a regionalização, intensificou-se a oposição de várias Secretarias em dividir atribuições com os territórios. Enquanto as ARs continuavam comandadas pela SIS, e mantinham-se como instâncias administrativas de segundo escalão, as Secretarias não "perderam" poder. Essa realidade se alterou quando os "Governos Locais" foram substituídos pelas Subprefeituras, com quem as Secretarias deveriam dividir atribuições e verbas. Em tais situações, segundo Thelen e Steinmo (1992), a análise institucional deve desnudar os interesses e relações de poder que incidem sobre a trajetória das políticas.

Segundo as entrevistas realizadas, a proposta de fazer dos "Governos Locais" uma transição administrativa para as Subprefeituras teve o resultado oposto. Para o assessor da Subprefeitura da Capela do Socorro, criou-se um paradoxo que afetou a produção de políticas nas regiões. No "Governo Local", os representantes das Secretarias não tinham incumbências administrativas; com as Subprefeituras tornaram-se coordenadores regionais sobrecarregados de tarefas organizacionais. A ação desconcentrada dos "Governos Locais", focada em projetos integrados, cedeu espaço às atividades administrativas e de caráter setorial nas Coordenadorias regionais (Entrevista ao autor, 21 jun. 2010). O que deveria servir para organizar as Subprefeituras não criou bases organizacionais e nem ampliou a disposição política das Secretarias municipais nessa direção. Políticas que já possuíam estruturas desconcentradas, como a assistência social, ou com mais recursos, como a educação, receavam que as Subprefeituras, carentes de estrutura administrativa, interferissem em sua autonomia setorial. Por isso, para Weir (1992), reformas organizacionais e revisão de iniciativas governamentais podem ser pré-requisitos para institucionalizar novas políticas, reposicionam os atores políticos e demandam coalizões que devem ser analisadas para verificar por que alguns segmentos são favorecidos em detrimento de outros.

O segundo momento iniciou em julho com a aprovação da Lei n. 13399 regulamentando a Lei Orgânica Municipal (LOM) que determina que "a administração municipal será exercida, em nível local, através de Subprefeituras". Estas passaram a ter poder formal de decisão, planejamento, investimento e autonomia administrativa. A lei igualou Subprefeitos e Secretários 
como auxiliares diretos do Prefeito, definiu as Subprefeituras como representantes locais da administração municipal e as transformou em unidades orçamentárias. Em tese, o Subprefeito seria o representante local do governo com mais poder decisório que os administradores regionais (Santos \& Barretta 2004). Mas conforme Dahl (1989), ao explicitar esses objetivos o governo criou uma "área em questão" que permitiu aos atores políticos adaptarem suas estratégias nessa arena política.

Pela lei, as Subprefeituras dividiram-se em sete coordenadorias. Na Coordenadoria de Ação Social e Desenvolvimento havia atividades de cinco Secretarias: Abastecimento, Assistência Social, Esportes e Lazer, Cultura e Trabalho. A Coordenadoria de Administração e Finanças reuniu duas Secretarias: Gestão Pública e Finanças e Desenvolvimento. A Coordenadoria de Planejamento e Desenvolvimento Urbano englobou quatro secretarias (Planejamento, Habitação, Transportes e do Verde e Meio Ambiente). A Coordenadoria de Manutenção e Infraestrutura Urbana, as atividades da Secretaria de Infraestrutura Urbana e do Departamento de Limpeza Urbana; a Coordenadoria de Projetos e Obras Novas, as funções da Secretaria Municipal de Serviços e Obras (Departamento de Edificações). Educação e saúde possuíam coordenações próprias pelo seu porte e gestão orçamentária separada dos recursos recebidos do governo federal. No gabinete do Subprefeito se localizaram pastas como Comunicação, Negócios Jurídicos, Governo e Segurança Urbana Defesa Civil). A dimensão da transferência de atividades aos territórios é um indicador dos desafios políticos que existiram para viabilizá-la junto às Secretarias.

No segundo semestre de 2002, o debate no Executivo centrou-se em duas questões: negociar com as Secretarias o que e como descentralizar e o organograma das Subprefeituras. Houve dificuldade de se gerar consensos entre a Secretaria Municipal das Subprefeituras, criada pela mesma lei para coordenar a descentralização no lugar da SIS, as Secretarias setoriais e as Subprefeituras. Este embate influiu na configuração institucional das Subprefeituras, pois as Secretarias sugeriram distintos caminhos para descentralizar suas políticas. Inexistia um projeto mais bem definido para avançar, além de objetivos e da visão normativa geral, na implantação das Subprefeituras. Assim, conforme Weir (1992), a maneira como o governo tratou essa política gerou problemas de interação político-administrativa e intensificou as disputas entre suas unidades, pois incidiu sobre as relações historicamente constituídas entre os órgãos. O organograma das Subprefeituras é mostrado no Diagrama 1.

Após a aprovação da lei, o governo previa que ocorreria a adesão das Secretarias à descentralização. Apenas após esse momento abriu-se a discussão para as Secretarias indicarem o que entendiam passível de ser repassado às Subprefeituras. Tal expediente evidenciava a falta de um projeto mais bem estruturado de descentralização, já que inexistia um modelo orientador para o debate governamental. O resultado foi que as Secretarias buscaram justificar como deveria ser a sua organização setorial no território ou apresentaram razões para manterem centralizadas várias atividades. O governo não logrou êxito em construir um consenso das distintas das Secretarias no arcabouço institucional previsto para as Subprefeituras, pois surgiram conflitos entre os grupos políticos nessa reorganização do poder público.

Essa situação é identificada no caderno "Documentos sobre a descentralização político-administrativa do Município de São Paulo”, organizado pela SMSP em outubro de 2002. Nesse material estão as respostas das Secretarias ao ofício que requeria suas propostas para a descentralização. Para evidenciar as divergências das Secretarias, abaixo apresentam-se os argumentos de algumas políticas sociais que eram consideradas a grande inovação da gestão local inter-setorial. Ou seja: o desenho institucional do Estado pode estreitar o curso 


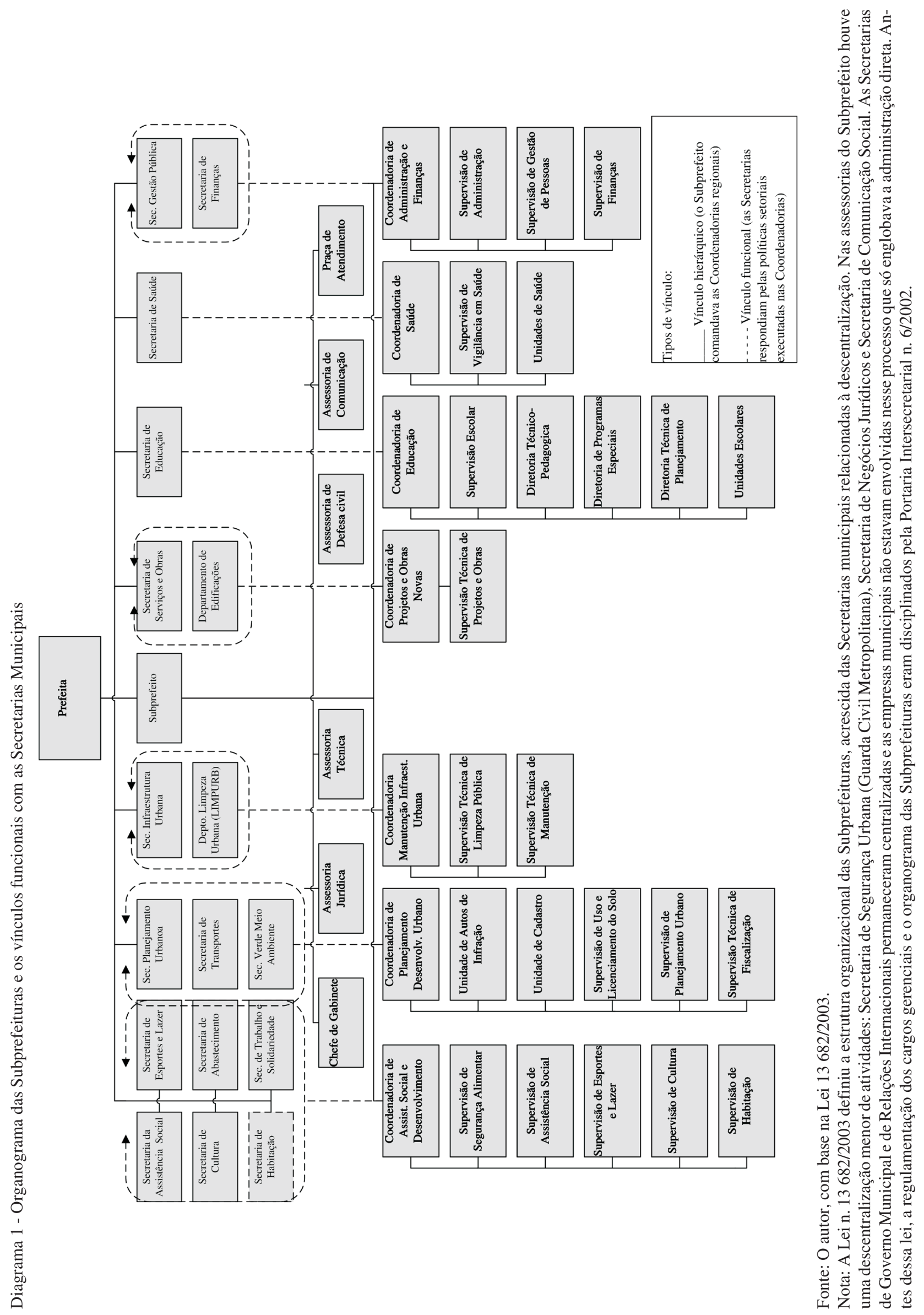


da inovação política se os atores políticos buscam manter seus interesses considerando, nesse caso, a dependência da trajetória de organização setorial das políticas, como se vê pelos exemplos abaixo. Para Olsen (1984), quando políticas "são inseridas em instituições", afetam as aspirações dos atores políticos e alteram suas ações.

$\mathrm{Na}$ Coordenadoria de Ação Social e Desenvolvimento, a Secretaria da Assistência Social (SMAS) protagonizou a maior disputa com a SMSP sobre a descentralização setorial ao reivindicar a organização de uma Supervisão Regional de Assistência Social vinculada ao Subprefeito. Em uma correspondência de 25 out. 2002, a Secretária assim dirigiu-se ao Secretário da SMSP: "desconheço os motivos que levaram V. Exa. ou a equipe dessa pasta a deletar a política de assistência social da gestão regional". A Secretária requeria uma estrutura organizacional e unidade orçamentária própria em vez de integrar a rubrica de administração das Subprefeituras. Justificava-se esse desmembramento pelo estágio adiantado da descentralização frente a outras áreas. Para a Secretária (Entrevista ao autor, 10 mar. 2010), havia risco de involução de políticas caso fossem descentralizadas sem critérios técnicos.

Na transição para as Subprefeituras, a SMAS manteve centralizada a homologação de convênios, meio central para executar suas ações, e a definição da política setorial. A descentralização limitou-se a aspectos administrativos como o suprimento de material básico para as Supervisões Regionais e a avaliação de imóveis para o conveniamento de entidades. Além disso, propunha-se uma área exclusiva de documentação/informação e a administração de pessoal gerenciada pelas Supervisões locais para atender as demandas setoriais. No fim desse debate as Supervisões de Assistência Social foram mantidas nas Coordenadorias de Ação Social e Desenvolvimento das Subprefeituras. Mas um indicador da discordância da área sobre a descentralização é que apenas em outubro 2004, no final do governo, o Decreto n. 45 438/2004 transferiu às regiões os Centros de Convivência.

A Secretaria de Habitação e Desenvolvimento Urbano (Sehab) propunha descentralizar serviços como regularização fundiária e aprovação de arruamento. Mas apenas em fevereiro de 2004 (Decreto n. 44 418) normatizou-se a primeira etapa de descentralização de atribuições, o que indica as resistências da pasta. O planejamento e a execução da política habitacional de interesse social, centrada na regularização de assentamentos precários e urbanização de favelas, mantiveram-se centralizadas na Sehab. Essa posição baseava-se na concepção de descentralização adotada pelo órgão, focada em estreitar vínculos com as Associações Comunitárias sem a mediação das Subprefeituras.

A Secretaria Municipal da Educação considerava a Coordenadoria de Educação sua representante regional e uma unidade orçamentária com atribuições de planejar e administrar recursos financeiros, materiais e humanos. Tal proposta contrariava a concepção de implantar uma Coordenação de Administração e Finanças nas Subprefeituras para apoiar todas as políticas descentralizadas. Na visão da Secretaria de Educação, a área teria uma diretoria de recursos humanos e uma diretoria financeira para manter sua autonomia funcional. A mesma independência de atuação apresentava-se na implantação da política de comunicação, na manutenção e zeladoria dos prédios utilizados pela Coordenadoria. O argumento era que a "descentralização" da Prefeitura não pode "centralizar" atividades nas Subprefeituras que desconsiderassem as diversidades setoriais. A descentralização administrativa restrita ao âmbito dessa política expressava o temor da divisão de recursos financeiros com outras áreas.

Nesse ano ainda ocorreu o debate sobre reforma administrativa do nível central, que também gerou divergências no governo. A SMSP compreendia as 
Subprefeituras como protagonistas, mas não isoladas, da reorganização política e democrática do Estado em nível municipal. A descentralização exigiria rever estruturas e funções das Secretarias para compatibilizá-las com o modelo organizativo das Subprefeituras. O projeto apresentado pelo então Secretário da SMSP foi concebido na AR de Capela do Socorro, região que era sua base política (informação confirmada ao autor pelo então Subprefeito da região, 22 abr. 2010). O redesenho da administração central apresentado pela SMSP ao núcleo do governo não foi aceito, excetuado um compromisso genérico na Lei n. 13 399: até janeiro de 2004, a estrutura e quadro de pessoal das Secretarias seriam compatibilizados para evitar duplicidades. A Lei n. 13 682/2003 prorrogou tal ação para dezembro de 2004, mas não foi implantada até o final da gestão.

Essa proposta não progrediu porque: (i) a perda de poder das Secretarias para as Subprefeituras desestabilizaria a divisão interna de espaços no governo, sobretudo entre as correntes internas do PT hegemônicas na esfera central; (ii) o acordo do governo com os vereadores da sua coalizão, especialmente do PT, de aceitar indicações para Subprefeitos e cargos diretivos locais seria "pressionado" pela redução das estruturas centrais. Para Weir (1992), o governo pode retrabalhar uma política para torná-la aceitável junto a alguns atores políticos e, ao recuar de suas intenções manifestas, reduz o apoio em outras arenas de políticas. A forma como se trata uma política pode gerar problemas de interação político-administrativa e as dificuldades de relacionamento entre unidades do governo. Ademais, estava em jogo a trajetória prévia da lógica distributiva com os empregos públicos existentes nas regiões.

Para ilustrar esse ponto, nas Secretarias municipais, instância responsável pela descentralização, veja-se a sua direção política em dois períodos. No biênio inicial (2001-2002) existiam 20 Secretarias e o PT ocupava 13 e em outra duas (Educação e Planejamento Urbano) os titulares diziam-se simpatizantes do partido. Duas pastas (Verde e Meio Ambiente e Negócios Jurídicos) eram dirigidas, respectivamente, por uma técnica que já atuara no governo Mário Covas (PSDB) e por uma professora da PUC-SP. Nas outras três pastas: Finanças e Desenvolvimento (PMDB), Bem-Estar Social (PSB) e Esportes e Lazer (PCdoB). No biênio 2003-2004, a hegemonia do PT ampliou-se (agora com 21 Secretarias com a criação da pasta da Segurança Urbana): o partido passou a dirigir 18 Secretarias, Planejamento Urbano manteve o titular, Esportes e Lazer continuou com o PCdoB e a Saúde passou a ser ocupada por um técnico com trânsito entre o PT e o PSDB.

Mas reorganizar a estrutura central teriam impacto sobre a divisão de poder negociada com os vários setores do PT na Prefeitura municipal. Possivelmente a ampliação do número de Secretarias ocupadas pelo PT a partir de 2003 já tenha sido reflexo da política de alianças que franqueou espaços também para vereadores de outros partidos nas Subprefeituras. Nesse cenário, era pouco provável que a administração direta no nível central fosse redimensionada, pois conforme Mollenkopf (1994), a coalizão política dominante deve ser capaz de administrar as tensões que inevitavelmente surgem das diferenças de interesse entre sua base eleitoral e seus aliados no governo.

Esse debate ainda suscitou divergências no interior do próprio núcleo político do governo, pois o secretário da SMSP abriu várias frentes de disputa com Secretarias resistentes às Subprefeituras. Ademais, esse Secretário assumira grande protagonismo na condução política da descentralização que, se encaminhado como propunha, ampliaria seu poder junto aos territórios e poderia aumentar seu peso político na sucessão da Prefeita em 2004. Para reduzir essa influência, a saída foi criar um colegiado formado pela SMSP, Secretaria de Gestão Pública (SGP) e Secretaria de Governo Municipal (SGM). Os três 
grupos concorrentes internos, através do Decreto n. 42561 (30 out. 2002), passaram a ser os "órgãos incumbidos de coordenar a referida descentralização". A partir de então, as questões acerca das Subprefeituras foram tratadas nessa comissão visando a aproximar os interesses conflitantes.

Alterou-se a direção política da descentralização ao buscar equilibrar-se o poder entre os grupos concorrentes do Secretário da SGM e a crescente influência da família do Secretário da SMSP no Executivo e no diretório municipal do PT. A constituição desse colegiado parece ter representado uma inflexão definitiva do governo sobre o alcance inovador das Subprefeituras. As Subprefeituras se orientaram para a descentralização administrativa de serviços, recursos materiais e humanos que, em grande medida, já atuavam de forma desconcentrada nas regiões.

Em termos administrativos, manter inalteradas as estruturas do nível central, e ao mesmo tempo implantar as Subprefeituras, gerou um modelo organizacional com dois vetores contraditórios. Havia 21 secretarias na administração direta que deveriam relacionar-se com sete coordenadorias nas Subprefeituras. No nível central permaneceram estruturas setoriais temerosas de perder poder às regiões, mas nas Subprefeituras o desenho organizacional pretendido era a inter-setorialidade nas ações. Por isso, para Thelen e Steinmo (1992), a análise institucional deve desnudar os interesses e relações de poder que influem na arenas de políticas. Estes são fatores de "dinamismo institucional" que podem afetar o jogo político, sobretudo se velhas instituições são postas a serviço de novos fins.

O resultado foi um permanente desencontro gerencial e político entre a esfera central e as Subprefeituras. O caso mais significativo foi a Coordenadoria de Assistência Social e Desenvolvimento que gerenciava atividades de cinco órgãos que operavam de forma desintegrada no nível central. Em situações como essa, ações locais de caráter inter-setorial demandavam decisões de cinco secretarias municipais, sem que no nível central existissem instâncias para realizar tal mediação. Como não havia concordância de todas as Secretarias com a descentralização, era pequena a possibilidade de se criarem tais fóruns integrados na esfera central. Um efeito não previsto dessa oposição foi transformar as Secretarias, e não as Subprefeituras, em protagonistas da descentralização, pois passaram a condicionar a forma, o ritmo e o seu conteúdo. É nesse sentido que a implantação das Subprefeituras foi errática, limitada em alcance administrativo e desigual na capacidade de gerir políticas públicas nas regiões, o que impactou sua capacidade de inovar na gestão local.

\section{V.3. Os anos 2003 e 2004: os limites e impasses na implantação das Subprefeituras}

Para implantar a Lei n. 13 399, desde o início de 2003, transferiram-se unidades administrativas das Secretarias às Subprefeituras para formalizar suas atribuições sobre serviços e equipamentos já desconcentrados. Coube às Subprefeituras: (i) gestão dos equipamentos de esportes (Decreto n. 42 770); (ii) gestão dos equipamentos de educação (Decreto n. 42 773); (iii) gestão dos equipamentos de saúde (decreto 42771); (iv) gestão dos equipamentos de cultura (Decreto n. 42 772). Nessas quatro áreas também transferiram-se bens patrimoniais, serviços e pessoal; (v) desconcentração do Programa de Silêncio Urbano (PISU) da Secretaria de Abastecimento para cinco Núcleos Regionais (Decreto n. 43 799); (vi) administração e fiscalização dos mercados municipais oriundos da Secretaria de Abastecimento (Decreto n. 43 796); (viii) transferência dos Centros Educacionais Unificados (CEUs) (Decreto n. 43 822). Em um ano, conforme a Tabela 2, as Subprefeituras assumiram 72,8\% do total de servidores municipais. 
Tabela 2 - Servidores transferidos da administração central para as Subprefeituras

\begin{tabular}{|c|c|c|c|}
\hline Servidores ativos & Março de 2003 & Março de 2004 & Variação \% (2003-2004) \\
\hline Subprefeituras & - & 96257 & - \\
\hline Educação & 68369 & 1396 & $-97,96$ \\
\hline SMSP & 10115 & 2832 & $-73,07$ \\
\hline Saúde & 19150 & 5328 & $-72,18$ \\
\hline Esportes & 1644 & 511 & $-68,92$ \\
\hline Abastecimento & 876 & 568 & $-35,16$ \\
\hline Cultura & 2516 & 1641 & $-34,78$ \\
\hline Governo & 767 & 679 & $-11,47$ \\
\hline Gestão Pública & 854 & 760 & $-11,01$ \\
\hline Assistência Social & 1764 & 1605 & $-9,01$ \\
\hline Autarquias da Saúde & 8764 & 8135 & $-7,18$ \\
\hline Planejamento & 200 & 188 & $-6,00$ \\
\hline Comunicação & 200 & 188 & $-6,00$ \\
\hline Transportes & 299 & 284 & $-5,02$ \\
\hline Infraestrutura & 442 & 421 & $-4,75$ \\
\hline Meio Ambiente & 917 & 898 & $-2,07$ \\
\hline Negócios Jurídicos & 1285 & 1283 & $-0,16$ \\
\hline Habitação & 747 & 747 & 0,00 \\
\hline Serviços e Obras & 781 & 805 & 3,07 \\
\hline Finanças & 1485 & 1542 & 3,84 \\
\hline Trabalho & 58 & 63 & 8,62 \\
\hline Segurança Urbana & 5218 & 6089 & 16,69 \\
\hline Ouvidoria & 22 & 28 & 27,27 \\
\hline Relações Internacionais & 16 & 24 & 50 \\
\hline Total & 126889 & 132272 & \\
\hline
\end{tabular}

Fonte: Finatec (2004).

Desse montante, 69,6\% provinha da Secretaria de Educação (basicamente professores, funcionários e supervisores escolares). Da Secretaria da Saúde vieram 10,9\% de servidores que atuavam, sobretudo, nas Unidades de Saúde já desconcentradas. A Secretaria Municipal das Subprefeituras transferiu 7,6\% do total de servidores que já trabalhavam nos territórios, pois eram lotados na antiga Secretaria das Administrações Regionais. A Secretaria Municipal de Esportes e de Cultura, respectivamente, cederam 1,2\% e 0,9\% de servidores que atuavam em equipamentos já desconcentrados. Essas cinco áreas responderam por $90 \%$ do total de servidores cedidos às regiões. Na gestão de pessoas não houve descentralização, mas transferência formal da responsabilidade administrativa das Secretarias às Subprefeituras, sobretudo de atividades que já eram desconcentradas.

Para o governo, esse processo era a condição necessária implantar a intersetorialidade de políticas nas regiões (Santos \& Barretta 2004). Porém, como atingir tal objetivo com tamanha desigualdade na transferência de servidores e serviços? Prevaleceram duas lógicas no desenho institucional: (i) a realização de serviços de manutenção urbana, herança histórica dos Distritos de Obras desde a década de 50 e (ii) a oferta de serviços de saúde, educação e assistência social, que já ocorriam de forma desconcentrada. Essa foi a tônica da descen- 
tralização administrativa limitada, errática, desigual e irregular de políticas, insuficiente para garantir a prometida inovação política que descentralizasse poder e afastasse as "pequenas soberanias" do comando das políticas setoriais nas regiões.

Pode-se avaliar a Subprefeituras também pelo montante de recursos descentralizados. Em 2003, o valor foi de R $\$ 550$ milhões e para 2004 estimava-se quase R $\$ 3$ bilhões (20,9\% do orçamento municipal) (Gráfico 1). Mas no orçamento municipal, três áreas representavam pouco mais de 20\%: Educação $(12,6 \%)$, Manutenção e Infraestrutura $(4,84 \%)$ e Saúde $(2,68 \%)$, a despeito da ênfase do discurso do governo na descentralização. Segundo a PMSP (2004), essas três áreas totalizavam $96,31 \%$ do orçamento médio das Subprefeituras. Mas na Educação e Saúde, as verbas foram principalmente direcionadas ao pagamento de pessoal e custeio administrativo. Na zeladoria urbana já existia um porcentual do orçamento desde o período das ARs. Já a Coordenadoria de Assistência Social e Desenvolvimento, com suas seis políticas setoriais, respondia por apenas 1,82\% do orçamento médio das Subprefeituras e 0,0025\% do orçamento municipal (!). Assim, a descentralização e a gestão transversal de políticas nas regiões depararam-se com a desigualdade setorial de recursos orçamentários. As Coordenadorias de Infraestrutura Urbana, Educação e Saúde continuaram a atuar isoladamente, pois detinham grande parte da verba regionalizada. Assim, como sugerem Lowi (1964) e Skocpol (2002), analisar políticas emanadas do Estado permite identificar arenas de poder em que é possível conhecer os atores beneficiados e desfavorecidos.

A condução da descentralização pelas Secretarias municipais gerava dois outros problemas. O primeiro, para a Subprefeita da Freguesia do Ó (Entrevista ao autor, 19 mar. 2010), era que as prioridades e alocação de recursos pelas Secretarias nem sempre coincidiam com as demandas locais. O segundo, como as Secretarias temiam a autonomia das "prefeiturinhas" e a perda de controle político nas regiões buscaram constituir vínculos diretos com os Coordenadores locais. Na assistência social, por exemplo, essa relação com as Supervisões Regionais, sem a mediação da Coordenadoria regional e do Subprefeito, foi a regra. Não ocorreu a "intervenção das práticas inter-setoriais nas relações de poder já estabelecidas nas estruturas centralizadas" (Fernandez \& Mendes

Gráfico 1 - Execução orçamentária descentralizada (Local, Administração Regional/Subprefeituras)

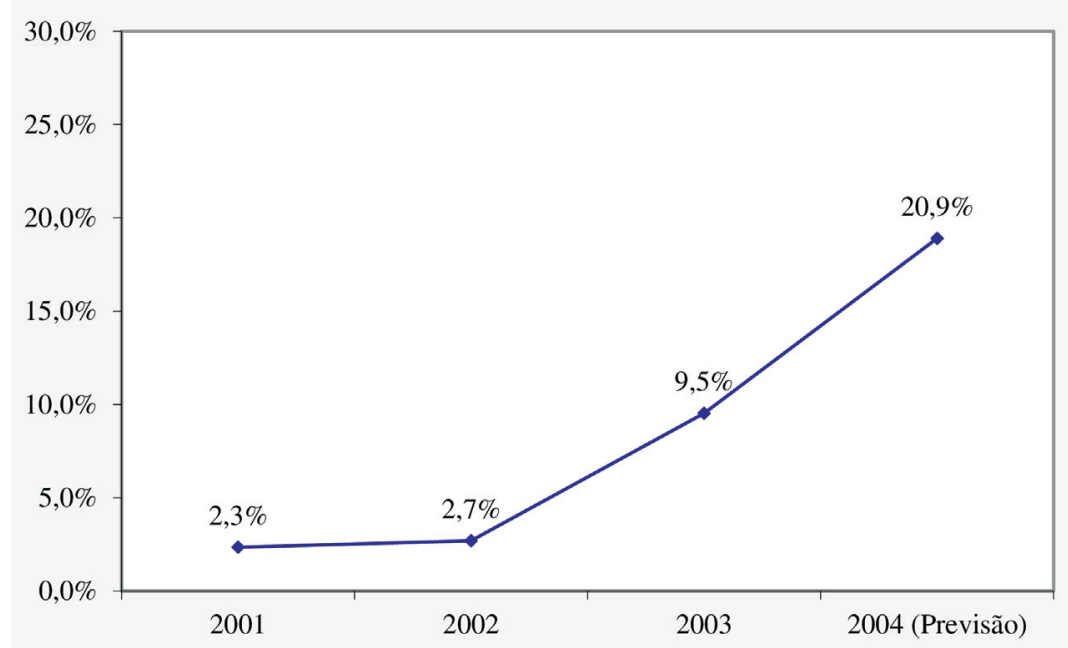

Fonte: Finatec (2004). 
2003, p.17), pois mantiveram-se os feudos políticos e organizacionais que Dahl (1989) chama de "pequenas soberanias".

Ainda havia o problema da indefinição sobre a subordinação dos Coordenadores aos Secretários municipais ou ao Subprefeito. Alguns coordenadores, mesmo com autoridade legal sobre os serviços descentralizados, reforçavam padrões de comando centralizado ao solicitar autorização às Secretarias. Essa foi a origem dos conflitos de poder entre Secretários (apegados à gestão desconcentrada) e Subprefeitos (que assumiram a gestão descentralizada). Também houve disputa para indicar os Coordenadores: embora o Subprefeito tivesse status de Secretário e autoridade administrativa formal para nomeá-los, para as Secretarias a política setorial não podia ser contrariada. Tal situação revela a fragilidade da descentralização para lidar com os conflitos funcionais (Secretarias vs. Subprefeitos) e territoriais (Subprefeito vs. Coordenadores). Assim, para Immergut (1992) e Thelen e Steinmo (1992), mudanças no jogo político podem afetar o funcionamento institucional e gerar distintos padrões de comportamentos dos atores políticos em uma mesma arena de políticas.

Contudo, os Subprefeitos e os Coordenadores foram majoritariamente indicados pelos vereadores. Tanto que a Lei n. 13 682/2003, que definiu a estrutura de cargos das Subprefeituras, criou uma salvaguarda nesse mecanismo: os indicados para as Supervisões de Habitação, Segurança Alimentar, Assistência Social, Cultura, Esportes e Lazer seriam nomeados somente após a oitiva das respectivas Secretarias. Buscava-se reduzir a influência dos vereadores com a avaliação técnica dos candidatos. Essa intenção foi confirmada pela Chefe de Gabinete da SMAS no biênio 2003/2004 e responsável por coordenar as indicações para as Supervisões de Assistência Social (Entrevista ao autor, 19 mar. 2010).

Pela Lei n. 13 682, os cargos de livre nomeação em cada Subprefeitura eram 14: Subprefeito, Chefe de Gabinete, cinco assessorias (jurídica, técnica, comunicação, defesa civil e Praça de Atendimento) e sete Coordenadores. Havia ainda 47 cargos de chefia, geralmente ocupados por servidores municipais. As 31 Subprefeituras possuíam 1891 postos diretivos (434 cargos de livre nomeação e 1457 funções de chefia). Essa estrutura serviu de recurso político para o governo ampliar sua coalizão de apoio junto aos vereadores, como será visto adiante. Paradoxalmente, a inovação proposta pelas Subprefeituras exponenciou a disputa dos vereadores por influência local, pois passou a existir mais verbas e cargos em jogo, em linha com Lowi (1964) e Skocpol (2002) sobre o alcance e características das políticas distributivas.

\section{As subprefeituras e a democracia participativa reduzida}

No discurso, as Subprefeituras seriam "áreas de poder para repensar as formas de exercer o comando político da cidade" e o controle social por meio do Orçamento Participativo (OP) seria chave. Na prática, a política de governo secundarizou esse processo. O debate sobre a participação popular esteve na agenda do governo desde seu início, mas a estratégia de estreitar os vínculos do PT com os movimentos sociais, além de estimular a participação local, foi secundarizada pelo governo municipal. A importância que os vereadores ganharam como fiadores da governabilidade reduziu o "participacionismo" a um papel secundário na política do Executivo. A implantação do OP ocorreu por ser uma bandeira histórica de governos petistas e para atender setores do partido que defendiam essa tese nos bairros. O OP foi politicamente importante para o PT manter o que Dahl (1989) chama de "fachada democrática" e a ideia da divisão de atribuições entre sociedade e governo. 
O OP iniciou sua implantação em 2001 e sua gestão cabia à Coordenadoria do Orçamento Participativo (Conop), vinculada ao Gabinete da Prefeita, mas sem que essa localização refletisse sua importância na ação governamental, pois segundo Vitale (2004, p.30):

"[...] o expressivo número de conselheiros do governo na composição do Conop ocorre em função da inexistência de uma coordenação-geral de planejamento e da ação de governo. Na ausência de um órgão responsável pelo planejamento geral, a participação de diversas secretarias no Conselho foi a maneira encontrada para se promover maior integração entre os próprios setores do governo e entre eles e o OP".

Outro problema foram as plenárias temáticas, introduzidas em 2002: suas deliberações não se convertiam em investimentos ao gerarem apenas diretrizes políticas que deixavam o governo com grande autonomia para priorizar as escolhas da população ao distribuir recursos nas regiões (idem). Assim, tanto nas demandas territoriais ou temáticas, a sociedade tinha pouca liberdade para decidir onde investir e pouco controle sobre as ações do governo.

Mas o principal indicador da baixa prioridade do OP na ação governamental foi seu porcentual no orçamento municipal. Para Bello (2006), inexistiu uma definição desse montante, conforme critérios como parcelas do orçamento não comprometidas com outras despesas ou investimentos. Segundo informações da PMSP, Belo (idem) mostra que o volume de recursos destinado ao OP abrangeu 5\% do orçamento previsto para 2002 e 6,2\% para 2003. Mesmo o aumento de $37 \%$ no período foi pequeno, diante da experiência de Porto Alegre, onde o OP distribuiu de 9\% a 15\% dos recursos entre 1991 e 2000. Esse parâmetro é chave, pois mostra a magnitude de valores sobre os quais a prefeitura abre mão da sua prerrogativa unilateral de decisão em favor dos processos participativos.

Paradoxalmente, a redução do peso orçamentário do OP ampliou-se em 2004, após a criação das Subprefeituras, apesar de o governo ampliar esse processo para todas as políticas públicas descentralizadas, além de saúde, educação e melhorias de bairro que já eram debatidas desde 2001. Em tese, isso aumentaria os porcentuais orçamentários para deliberação no OP. Contudo, houve uma piora, pois apenas 4,9\% do orçamento total (redução de R $\$ 662$ em 2003 milhões para 560 milhões em 2004) foram disponibilizados para o OP. Mesmo com a sua ampliação para as sete coordenadorias temáticas, saúde e educação responderam por 93,9\% em 2003 e 72,9\% em 2004 (idem). As políticas de assistência social, esporte, cultura e meio ambiente responderam, em 2004, por 2,6\% do total deliberado. Assim, o OP pautou-se pelas prioridades do Executivo, centrou-se em áreas com mais recursos (saúde e educação) e não ampliou gastos em outras políticas sociais descentralizadas.

A criação das Subprefeituras não fez do OP uma política central de governo para as regiões. A aproximação do OP da estrutura organizativa das Subprefeituras foi na direção contrária da integração de políticas nos territórios ao aprofundar as demandas segmentadas em cada Coordenadoria. Esse modelo fragmentado mostrava que tratar da gestão municipal como um todo estava fora do escopo do OP, o que também lhe conferia reduzida relevância na estratégia governamental. Conforme Mollenkopf (1994), a coalizão dominante é uma aliança tática entre diferentes interesses que busca obter a cooperação com outros centros de poder para governar. Como isso implica escolhas políticas, o governo nem sempre confere inequívoco suporte aos membros de sua coalizão original, pois quando e como apoiá-los depende de objetivos políticos maiores (Dahl 1989).

Em se tratando de definir não a relevância de dividir poder, mas quanto e em que grau fazê-lo, o tema tornou-se mais complexo no governo (Vitale 2004). 
Para Tatagiba e Teixeira (2005, p.7), o OP não tornou-se um "item na reforma democrática do Estado e de construção da governabilidade". Também distinguiu-se da experiência de Porto Alegre onde, para Dias (2000), o governo instrumentalizou o confronto do OP (democracia participativa) com os vereadores (democracia representativa). Em São Paulo, para o Coordenador do OP (Entrevista ao autor, 20 ago. 2010), a negociação entre o OP e o parlamento guiou-se por outra estratégia. Na gestão local, a ênfase passou a ser atender os interesses dos vereadores para ampliar a coalizão de governo, antes que conferir maior peso aos processos participativos. Por isso, para Arretche (1996), a descentralização, antes de gerar democracia e controle social, pode incentivar a patronagem com recursos públicos, como vê-se abaixo.

\section{Política de alianças e partilha do poder nas subprefeituras}

Conforme o programa de governo, os vereadores historicamente apropriaram-se das ARs impossibilitando separar o Executivo e o Legislativo na gestão municipal. O Legislativo deveria aprimorar os projetos do governo, fiscalizar o Executivo e tratar de temas municipais. Nas regiões, a gestão, com participação popular e controle social, caberia às Subprefeituras. Mas o governo também atribuía uma importância vital à construção de uma maioria parlamentar. No início, o governo Marta Suplicy era apoiado por uma bancada de 19 vereadores (16 do PT e três do PCdoB) e previam-se dificuldades para forjar uma maioria parlamentar. No início de 2002, em face da dificuldade de aprovar seus projetos no parlamento, o Executivo buscou aumentar sua base aliada com o discurso de um "governo amplo". Até abril, o governo havia obtido o apoio das bancadas do PMDB (seis vereadores) e do PL (três vereadores) com negociações que já envolviam cargos nas ARs. Com o PSB, a base governista de 30 parlamentares tornou-se majoritária (a Câmara tem 55 vereadores). Segundo Dahl (1989), quando o governo precisa de votos costuma estender seus favores ao parlamento.

Para ampliar a coalizão dominante, a criação das Subprefeituras serviu de recurso político em um contexto onde os vereadores temiam perder influência em seus redutos eleitorais, pois se Executivo indicasse os Subprefeitos poderia fortalecer as lideranças de bairro. A opção do governo de franquear aos vereadores a indicação de Subprefeitos e outros cargos está em linha com de Lowi (1964) e Skocpol sobre as políticas distributivas. Para Mollenkopf (1994), a coalizão dominante, para conciliar "interesses contraditórios", manteve a distribuição de empregos e outros benefícios. Ao aprovar as Subprefeituras, o governo criou um marco para consolidar sua política de alianças no parlamento a partir de julho de 2002. Mas o Executivo também mostrou que a democracia participativa não seria prioridade na gestão local e sim a divisão de poder com os vereadores, conforme expressou Antônio Donato, Secretário Municipal das Subprefeituras em 2003:

${ }^{4}$ Para Abranches (1988, p.21) o "presidencialismo de coalizão" tem como uma de suas causas o multipartidarismo que cobra distribuir ministérios segundo critérios partidários e estaduais. Constituir maiorias parlamentares com o apoio dos partidos seria quase a única saída para o Executivo superar o problema de bases de apoio fragmentadas, governar em minoria e evitar a paralisia decisória.
“[...] do ponto de vista do processo político, depois da Constituição de 1988, o país vive o chamado presidencialismo de coalizão ${ }^{4}$ : tem-se o parlamento forte, com uma multiplicidade de partidos, o que impõe a necessidade de construir alianças para governar, pois a minoria no parlamento significa um grave problema de governabilidade. A aprovação da lei das Subprefeituras passou por essa discussão, inclusive resultando na participação de partidos aliados na administração das Subprefeituras. Podemos dizer que o governo Marta arquitetou uma maioria parlamentar e o terreno prioritário dos acordos foi o das Subprefeituras" (Donato 2006, pp.41-42).

Essa forma de partilhar o poder com os vereadores nas Subprefeituras materializou-se no início de 2003. A Tabela 3 mostra como as Subprefeituras serviram para ampliar a coalizão de governo, se comparada com a divisão política das ARs que, até o final de 2002, retratava centralmente a coalizão 
Tabela 3 - Indicações nas ARs (2001/2002) e nas Subprefeituras (2003-2004)

\begin{tabular}{|c|c|c|c|}
\hline \multicolumn{2}{|c|}{ Administrações Regionais } & \multicolumn{2}{|l|}{ Subprefeituras } \\
\hline \multicolumn{2}{|c|}{ Aliança eleitoral $(2001,2002)$} & \multicolumn{2}{|c|}{ Aliança de governo $(2003,2004)$} \\
\hline Territórios & Indicação do AR & Indicação do Subprefeito & Outros Cargos \\
\hline Aricanduva & Não obtida & Celso Jatene (PTB) & Antônio Rodrigues (PL) \\
\hline Butantã & Sem partido & $\begin{array}{l}\text { Ex-Secretário da Subprefeituras } \\
\text { Antônio Donato (PT) }\end{array}$ & $\begin{array}{l}\text { Sec. Subprefeituras Carlos Zaratini } \\
\text { (PT) }\end{array}$ \\
\hline Campo Limpo & $\mathrm{PT}$ & Antônio Rodrigues (PL) & Dep. Vicente Cândido (PT) \\
\hline Casa Verde & PT & Rubens Calvo (PT) & Eliseu Gabriel (PSB) \\
\hline Capela do Socorro & PT & ArselinoTatto (PT) & $\begin{array}{l}\text { Edivaldo Estima (PPB), Milton Leite } \\
\text { (PMDB), Antônio Goulart (PMDB) }\end{array}$ \\
\hline Cidade Ademar & PT & Dep. Est. Italo Cardoso (PT) & Não obtidas \\
\hline Cidade Tiradentes & Criada em 2002 & $\begin{array}{l}\text { Claudete Alves (PT), Dep. Fed. } \\
\text { Arlindo Chinaglia (PT) }\end{array}$ & Paulo Frange (PTB) \\
\hline Ermelino Matarazzo & PCdoB & Dep. Ana Martins (PCdoB) & $\begin{array}{l}\text { Dep. Devanir Ribeiro (PT), Alcides } \\
\text { Amazonas (PCdoB) }\end{array}$ \\
\hline Freguesia do Ó & PT & Viviani Ferraz (PL), Baratão (PDT) & José Américo (PT) \\
\hline Guaianases & PT & Beto Custódio (PT) & José Ferreira (Zelão) (PT) \\
\hline Ipiranga & PT & Dep. Fed. José Mentor (PT) & Jooji Hato (PMDB) \\
\hline Itaim Paulista & PT & João Antônio (PT) & Não obtidas \\
\hline Itaquera & PCdoB & Toninho Paiva (PL) & Adriano Diogo (PT) \\
\hline Jabaquara & PCdoB & Francisco Chagas (PT) & Roger Lin (PSB) \\
\hline Lapa & PT & Augusto Campos (PT) & Paulo Frange (PTB) \\
\hline M'Boi Mirim & Criada em 2002 & Lucila Pizani (PT) & $\begin{array}{l}\text { Milton Leite (PMDB), Dep. Vicente } \\
\text { Cândido (PT) }\end{array}$ \\
\hline Mooca & PT & Adriano Diogo (PT) & Myriam Athiê (PMDB) \\
\hline Parelheiros & Criada em 2002 & Edivaldo Estima (PPB) & Não obtidas \\
\hline Penha & PT & João Antônio (PT) & Toninho Campanha (PDT) \\
\hline Perus & PT & Raul Cortez (PPS) & Eliseu Gabriel (PSB) \\
\hline Pinheiros & PT & Indicação do Executivo & Não obtidas \\
\hline Pirituba & PT & José Laurindo (PT) & Eliseu Gabriel (PSB) \\
\hline Santana & PT & Carlos Apolinário (PDT) & $\begin{array}{l}\text { Celso Cardoso (PFL), Humberto } \\
\text { Martins (PMDB), José Olímpio } \\
\text { (PMDB) }\end{array}$ \\
\hline Santo Amaro & PT & Antônio Goulart (PMDB) & Dep. Est. Italo Cardoso (PT) \\
\hline São Mateus & PT & Francisco Chagas (PT) & Dep. Devanir Ribeiro (PT) \\
\hline S. Miguel Paulista & PT & $\begin{array}{l}\text { Paulo Teixeira (Sec. Municipal de } \\
\text { Habitação) }\end{array}$ & $\begin{array}{l}\text { Paulo Frange (PTB), João Antônio } \\
\text { (PT) }\end{array}$ \\
\hline Sé & PT & Indicação do executivo & Não obtidas \\
\hline Tremembé, Jaçanã & PT & Dep. José Mentor (PT) & Carlos Apolinário (PDT) \\
\hline Vila Prudente & PT & Flávia Pereira (PT) & Francisco Chagas (PT) \\
\hline Vila Maria & Sem partido & Wadih Mutran (PPB) & $\begin{array}{l}\text { Arselino Tatto (PT), Manoel Cruz } \\
\text { (PRONA) }\end{array}$ \\
\hline Vila Mariana & PT & José Américo (PT) & Antônio Rodrigues (PL) \\
\hline
\end{tabular}

Fontes: O autor, com base em matérias do Estado de São Paulo (30 jun. 2004) e Folha de São Paulo (29 dez. 2000), complementada pelas entrevistas realizadas com os Subprefeitos e Coordenadores das Subprefeituras de Capela do Socorro e Freguesia do Ó, durante o ano de 2010. 
5 Ainda que alguns vereadores tenham se filiado a outro partido entre 2001-2004, optou-se por manter sua identidade partidária original por retratar mais fidedignamente o amplo espectro da política de alianças.
${ }^{6} \mathrm{O}$ vereador Toninho Paiva (PL) expressou bem a posição dos parlamentares: "O PT não entendeu que não tem maioria na Casa e eles precisam de uma base de sustentação" (Estado de São Paulo, 12 jul. 2002). eleitoral entre PT e PCdoB. Pode-se ver que o PT manteve-se como o partido majoritário com $74 \%$ dos 31 Subprefeitos (23 regiões) e as outras oito dividiram-se entre sete partidos da coalizão governista. Para os cargos de segundo escalão, com os dados que foram possíveis de coletar, ao menos em 16 locais outros partidos, além da coalizão eleitoral, realizaram indicações. Esse processo ocorreu em 52\% das Subprefeituras, mas sem que o PT deixasse de ser majoritário, pois a participação dos aliados direcionou-se mais ao segundo escalão (cargos de Coordenação e Supervisão). Estes geralmente tinham um perfil mais de "bairro" por serem indicados pelos vereadores locais.

Assim, o "modelo político" prevalecente nas Subprefeituras caracterizou-se por: ( $i$ ) não ser uma entrega das regiões apenas para um partido ou vereador, mesmo que fosse do PT; (ii) manter a hegemonia política do PT na maioria das regiões; (iii) participação de aliados em um número menor de locais e em cargos de segundo escalão com menor peso político.

Desde então, os partidos da base aliada e o número de vereadores ${ }^{5}$ foram os seguintes: Partido Liberal (três), Partido Democrático Trabalhista (três), Partido Trabalhista (três), Partido Geral dos Trabalhadores (um), Partido da Frente Liberal (um), Partido Progressista Brasileiro (dois), Partido do Movimento Democrático Brasileiro (quatro), Partido Popular Socialista (dois), Partido Socialista Brasileiro (dois) e Partido da Reedificação da Ordem Nacional (um). Somado aos 19 vereadores do PT e do PCdoB, 42 formavam a coalizão governista. Todas as bancadas tiveram vereadores contemplados com indicações nas Subprefeituras e mesmo aqueles teoricamente oposicionistas como os do PFL, PPB e Prona votavam a favor do governo. Como diz Mollenkopf (1994), a coalizão política dominante refez alianças, secundarizou velhas clivagens políticas e unificou grupos contraditórios.

Para o que importa para a apoiar a hipótese, conformou-se uma associação de interesses de vereadores que há várias legislaturas já eram da base dos governos municipais, alguns desde a gestão Jânio Quadros-PTB (1985-1988), passando pelas gestões Paulo Maluf-PPB (1992-1996) e Celso Pitta-PPB (1997-2000). Entre esses parlamentares havia filiados ao $\mathrm{PL}^{6}, \mathrm{PPB}, \mathrm{PDT}, \mathrm{PGT}$, PPS, PTB e PMDB, cujo apoio aos governos sempre associou-se com a manutenção de sua influência política regional. Se a possibilidade do controle social nas Subprefeituras proposta pelo PT poderia pôr em risco a influência política desses vereadores; por outro lado, seu voto na Câmara Municipal foi a moeda política oferecida e aceita pelo Executivo nessa negociação. O governo do PT aceitou essa forma de barganha (para Mollenkopf (1994), isso é parte das "regras" que organizam a competição política municipal) ao priorizar a construção da governabilidade para aprovar projetos no parlamento. Esse grupo será chamado de vereadores "tradicionais", ainda que seu comportamento não tenha sido homogêneo, pois esse modus operandi predominou na sua ação.

Em vez de combater o fisiologismo, como anunciado em seu programa de governo, o PT majoritariamente aliou-se a essa prática política. No núcleo político do Executivo e na bancada petista predominaram os vereadores "pragmáticos", favoráveis à negociação com os vereadores protagonistas do "toma-lá-dá-cá" tradicional na política municipal. Essa ala foi majoritária contra os "democráticos", um grupo formado por vereadores de "opinião" e aqueles com trajetória política ligada às lutas nos bairros que defendiam ampliar o controle social. Desse grupo ainda participavam Subprefeitos, suas bases de apoio territorial de militantes do PT e movimentos sociais vinculados ao partido que, de forma geral, defendiam Subprefeituras sem a influência de vereadores, com controle social e participação popular.

Segundo Tatto (2006), Secretário de Governo Municipal em 2004, foi um erro a opção de governar as regiões com os vereadores para organizar sua 
coalizão de apoio na Câmara Municipal, pois: (i) a política de alianças no parlamento não foi assimilada pelas bases partidárias locais, sobretudo quando antigos adversários assumiram o comando de alguma regiões (por exemplo, na Freguesia do Ó, a Subprefeita do PT foi substituída por um ex-Administrador Regional malufista); (ii) a pressa em compor a maioria parlamentar gerou conflitos em bairros onde a nomeação do Subprefeito contrariou as lideranças locais. Para Mollenkopf (1994), a coalizão política dominante deve administrar as tensões derivadas das diferenças de interesse entre sua base eleitoral e os aliados no governo. Mas essa política da partilha de poder era de difícil solução: ao franquear aos vereadores que indicassem Subprefeitos dificultava que os territórios deixassem de ser seus feudos cativos.

\section{Conclusões}

Na conclusão é importante cotejar as hipóteses com as condições causais que incidiram na configuração das Subprefeituras. No discurso, administrativamente, as Subprefeituras aproximariam os serviços dos cidadãos com custos menores e maior qualidade. A maior inovação seria a inter-setorialidade de políticas reunidas nas sete coordenadorias temáticas. Mas a descentralização das políticas setoriais não foi uniforme. Cada Secretaria comportou-se de forma diferente e essa falta de unidade administrativa foi causada pelo temor desses órgãos perderem poder para as regiões. Agregue-se ainda o duplo comando ao qual estavam submetidas às Coordenadorias locais: hierarquicamente ligadas ao Subprefeito, mas dependentes da política oriunda da Secretaria setorial. Tal desenho criou distintas áreas de poder e gerou impasses administrativos sobre o comando das políticas locais. A visão de Secretarias formulando e monitorando políticas, cabendo às regiões executá-las, não logrou êxito e fez com que a descentralização administrativa fosse e sem uniformidade.

Como a reforma administrativa do nível central foi derrotada, manteve-se a relação conflituosa das Secretarias com as Coordenadorias regionais. Nos regiões previa-se unificar áreas que permaneceram isoladas no nível central, e não havia unidade de ação "em cima" que respaldasse a inter-setorialidade "em baixo". Esse desencontro influiu no fracasso da intersetorialidade ao fortalecer lógicas particularistas de atuação, pois cada Secretaria relacionava-se com sua contraparte local visando manter seu controle político. Some-se a isso que a divisão de influência setorial entre vereadores (os "tradicionais" e os "pragmáticos") e grupos do PT também incidiu para essa fragmentação. Presume-se que esse processo replicou-se de forma similar nas 31 Subprefeituras, pois o modelo político e gerencial e as Secretarias eram as mesmas, o que apoia a hipótese do caráter errático da descentralização.

Pelo discurso petista, a descentralização construiria o "poder local" e as Subprefeituras seriam apoiadas no controle social e na participação popular. As Subprefeituras seriam o antídoto para combater a falta de eficiência e de transparência das ARs. Sobretudo, as Subprefeituras eliminariam o monopólio das ARs pelos vereadores dos bairros e a forma como o governo se valia das mesmas distribuindo sinecuras para construir sua política de alianças. O parlamento deveria debater temas municipais e às Subprefeituras caberia a gestão local com apoio democrático da população.

Mas o governo manteve padrões fisiológicos na relação com os vereadores, similares àqueles criticados pelo PT como prática tradicional de cooptação. A partilha de poder nas regiões entre parlamentares petistas e dos demais partidos em nada diferiu, na forma e em seus resultados, do que Couto (1998) chamou de coalizão fisiológica de governo. Lembrando Dahl (1989), o objetivo do Prefeito é obter a aquiescência dos vereadores para suas políticas, o que geralmente se consegue com a máquina de empregos públicos. As Subprefeituras transfor- 
maram-se em recurso político para o governo ampliar sua coalizão de apoio. Essa é a explicação causal da prioridade conferida pelo governo à lógica da vereança, em linha com a prática histórica e recorrente na política municipal.

A outra parte dessa hipótese diz respeito à política do governo de secundarizar os mecanismos de democracia participativa nas regiões. Essa questão não pode ser desvinculada da prioridade que o Executivo conferiu à política de alianças com os vereadores para manter a governabilidade. O discurso petista de que a sociedade local, juntamente com os Subprefeitos, fiscalizaria os vereadores nos bairros foi abandonado. Conforme Dahl (1989), isso enfatiza seu caráter de que os governos costumam conferir aos formatos processos participativos que mais lhe convém. Nesse sentido, o debate sobre a participação popular foi desvinculado da criação das Subprefeituras, pois o governo temia pôr em risco a sua política de alianças. Entre fortalecer a democracia participativa ou estreitar os vínculos com os vereadores do PT e os partidos da base aliada, prevaleceu essa última na ação do Executivo. Essa opção política foi a causa para que o controle social, inclusive sobre os vereadores, fosse secundarizada diante da proeminência assumida pelos parlamentares nas Subprefeituras.

A participação dos vereadores nas Subprefeituras foi a tônica após 2003 e, apesar das diferenças nos modelos de partilha de poder em cada região, a forma como foram utilizadas para esse fim foi invariável. As condições causais que explicam a ação do governo em favor da divisão de poder com os vereadores foram as mesmas em todas localidades e derivaram da tese que era necessário construir uma maioria de apoio parlamentar para aprovar projetos e evitar o isolamento político ocorrido na gestão Erundina. Em vez do discurso da governabilidade suportada pela democracia participativa, prevaleceu o criticado "toma-lá-dá-cá" da política, considerado pelo PT como fisiológico e malufista. A inovação proposta pelas Subprefeituras acabou gradativamente limitada pelas práticas políticas institucionalizadas na competição política municipal. Caso o governo conseguisse implantar a sua proposta para as Subprefeituras, sem contrariar os interesses dos vereadores e das Secretarias municipais, as hipóteses desse artigo não poderiam ser aceitas, pois tal situação seria o contrafactual.

Eduardo José Grin (eduardo.grin@fgv.br) é Doutorando em Administração Pública e Governo pela Fundação Getúlio Vargas (FGV-SP), pesquisador do CEAPG (Centro de Estudos em Administração Pública e Governo) da Fundação Getúlio Vargas (FGV-SP) e professor do Centro Universitário Senac Santo Amaro, São Paulo. Afiliação Institucional: Fundação Getúlio Vargas, São Paulo, SP, Brasil.

\section{Referências}

Abranches, S.H., 1988. Presidencialismo de Coalizão: o dilema institucional brasileiro. Dados, 31(1), pp.5-34.

Abrucio, F.L., 2005. A coordenação federativa no Brasil: a experiência do período FHC e os desafios do governo Lula. Revista de Sociologia Política, 24, pp.41-67.

Almeida, M.H.T., s.d. Federalismo e proteção social: a experiência brasileira comparada. Disponível em: http://www.fflch.usp.br/dcp/assets/docs/MariaHerminia/federalismodef.pdf. Acesso: 19 jul. 2009. 2005. Recentralizando a Federação? 2005. Revista de Sociologia e Política, 24, pp.29-40.

Arretche, M.T.S., 1996. Mitos da descentralização: mais democracia e eficiência nas políticas públicas. Revista Brasileira de Ciências Sociais, 11(31), pp.44-66.

1999. Políticas sociais no Brasil: descentralização em um Estado Federativo. Dados, 14(40), pp.111-141.

2002. Federalismo e Relações Intergovernamentais no Brasil: A Reforma de Programas Sociais. Dados, 45(3), pp.431-458.

Bello, C.A., 2006. Orçamento, redistribuição e participação popular no Município de São Paulo. São Paulo em Perspectiva, 20(3), pp.95-105.

Boschi, R.R., 1999. Descentralização, clientelismo e capital social na governança urbana: comparando Belo Horizonte e Salvador. Dados, 42(4), pp.528-553. 
Capucci, P., 2004. Subprefeituras em São Paulo: o menor é melhor? In R. Garibe \& P. Capucci, eds. Gestão local nos territórios da cidade: ciclo de atividades com as subprefeituras. São Paulo: Mídia Alternativa.

Couto, C.G., 1998. Negociação, decisão e governo: padrões interativos na relação Executivo-Legislativo e o caso paulistano. In R.C. Andrade, ed. Processo de Governo no Município e no Estado. São Paulo: Edusp.

Dahl, R.A., 1958. A Critique of the Ruling Elite Model. The American Political Science Review, 52(2), pp.463-469. , 1961. Who Participates in Local Politics and Why. American Association for the Advancement of Science, 134(3487), pp.1340-1348. 1989. Who Governs? Democracy and Power in an American City. New Haven: Yale University Press.

Dias, M., 2000. Sob o signo da vontade popular: o Orçamento Participativo e o dilema da Câmara Municipal de Porto Alegre. Belo Horizonte/Rio de Janeiro: Editora da UFMG/Iuperj.

Donato, A., 2006. A descentralização em São Paulo. In R. Gaspar; M. Akerman \& R. Garibe, eds. Espaço urbano e inclusão social: a gestão pública na cidade de São Paulo (2001-2004). São Paulo: Fundação Perseu Abramo.

Falleti, T., 2006. Efeitos da descentralização nas relações intergovernamentais: o Brasil em perspectiva comparada. Sociologias, 16, pp.46-85.

Fernandez, J.C.A. \& Mendes, R., 2003. Subprefeituras em São Paulo e políticas públicas para qualidade de vida. São Paulo: Cepedoc.

Garibe, R., 2004. A descentralização do poder em São Paulo. In R. Garibe \& P. Capucci, eds. Gestão local nos territórios da cidade: ciclo de atividades com as subprefeituras. São Paulo: Mídia Alternativa. ,2006. Estado e descentralização. In R. Gaspar; M. Akerman \& R. Garibe, eds. Espaço urbano e inclusão social: a gestão pública na cidade de São Paulo (2001-2004). São Paulo: Editora Fundação Perseu Abramo.

Gerring, J., 2007. Case Study Research: Principles and Practices. Cambridge, UK: Cambridge University Press.

Immergut, E., 1992. The Rules of the Game: The Logic of Health Policy-Making in France, Switzerland, and Sweden. In S. Steinmo; K. Thelen \& F. Longstreth, eds. Structuring Politics: Historical Institutionalism in Comparative Analysis. Cambridge, UK: Cambridge University Press.

Jacobi, P., 1990. Descentralização municipal e participação dos cidadãos: apontamentos para o debate. Lua Nova, 20, pp.121-143.

, 1991. Políticas públicas e alternativas de inovação da gestão municipal: o complexo caso da cidade de São Paulo. São Paulo em Perspectiva, 5(2), pp.31-37.

Keinert, T.M.M., 1993. Reforma administrativa nos anos 90: o caso da prefeitura Municipal de São Paulo. Revista de Administração de Empresas, 33(4), pp.66-81.

King, D., 1992. The Establishment of Work-Welfare Programs in the United States and Britain: Politics, Ideas, and Institutions. In S. Steinmo; K. Thelen \& F. Longstreth, eds. Structuring Politics: Historical Institucionalism in Comparative Analysis. Cambridge, UK: Cambridge University Press.

Kugelmas, E. \& Sola, L., 1999. Recentralização/Descentralização: dinâmica do regime federativo no Brasil dos anos 90. Tempo Social, 11(2), pp.63-81.

Lameirão, C.R., 2007. Estratégias políticas e gestão local: as subprefeituras do município do Rio de Janeiro. Rio de Janeiro. Dissertação de Mestrado. Rio de Janeiro: Universidade Federal Fluminense.

Lowi, T.J., 1964. American Business, Public Policy, Case Studies, and Political Theory. World Politics, 16(4), pp.677-715.

Maquiavel, N., 1983. O Príncipe:escritos políticos. $3^{\text {a }}$ ed. São Paulo: Abril Cultural.

March, J.G \& Olsen, J.P., 1984. The New Institutionalism: Organizational Factors in Political Life. The American Political Science Review, 78(3), pp.734-749.

Martins, J.D., 2006. As regras da metrópole: campo urbanístico e ordem social na região metropolitana de São Paulo. Tese de Doutorado. Brasília: Universidade de Brasília.

Martins, M.L.R., 1997. Descentralização e Subprefeituras em São Paulo. Digit. Disponível em: http://www.usp.br/fau/depprojeto/labhab/biblioteca/textos/martins_descentralizaerundina.pdf. Acesso: 19 jul. 2010.

Melo, M.A., 1996. Crise federativa, guerra fiscal e "hobbesianismo municipal: efeitos perversos da descentralização? São Paulo em Perspectiva, 10(3), pp.11-20.

Mollenkopf, J.H., 1992. The Rise and Fall of the Koch Coalition in New York City Politics. New Jersey: Princeton University Press.

Polsby, N.W., 1960. How to Study Community Power: The Pluralist Alternative. The Journal of Politics, 22(3), pp.474-484.

Ragin, C.C., 1987. The Comparative Method: Moving beyond Qualitative and Quantitative Strategies. Jackson: University California Press.

Sader, E., 1992. Governar para Todos: uma avaliação da gestão Luiza Erundina. São Paulo: Scritta Editorial.

Santos, U.P \& Barretta, D., 2004. As Subprefeituras em São Paulo. São Paulo: Hucitec.

Skocpol, T., 2002. Bringing the State back in: Strategies of Analysis in Current Research. In P.B. Evans; D. Ruesschemeyer \& T. Skocpol, eds. Bringing the State back in. Cambridge, UK: Cambridge University Press.

Sposati, A., 2001. A cidade em pedaços. São Paulo: Editora Brasiliense. , 2002. Superando o discurso da descentralização municipal. In A.I. Calderón \& V. Chaia, eds. Gestão Municipal: descentralização e participação popular. São Paulo: Cortez.

Tatagiba, L.; Teixeira, A.C.C., 2005. Movimentos sociais e sistema político: os desafios da participação. Observatório dos Direitos do Cidadão: acompanhamento e análise das políticas públicas da cidade de São Paulo, 25. São Paulo: Instituto Polis/PUC-SP. 
Tatto, J., 2006. Governo Marta: eficiente e com prioridade. In R. Gaspar; M. Akerman \& R. Garibe, eds. Espaço urbano e inclusão social: a gestão pública na cidade de São Paulo (2001-2004). São Paulo: Fundação Perseu Abramo.

Teixeira, M.A.C., 2004. Negociação política e as formas de interação Executivo Legislativo no Brasil no período de 1983 a 1992. Cadernos Gestão Pública e Cidadania, 9(40), pp.1-82.

Thelen. K. \& Steinmo, S., 1992. Historical Institutionalism in Comparative Politics. In S. Steinmo; K. Thelen, K \& F. Longstreth, eds. Structuring Politics: Historical Institutionalism in Comparative Analysis. Cambridge, UK: Cambridge University Press.

Tilly, C., 1983. Big Structures, Large Process, Huge Comparisons. Michigan: University of Michigan Press.

Vitale, D., 2004. Orçamento Participativo em São Paulo (2001-2002). São Paulo: Instituto Polis.

Weir, M., 1992. Ideas and Politics of Bounded Innovation. In S. Steinmo; K. Thelen \& F. Longstreth, eds. Structuring Politics: Historical institutionalism in Comparative Analysis. Cambridge, UK: Cambridge University Press.

\section{Outras fontes}

Câmara Municipal de São Paulo. Lei Orgânica do Município de São Paulo. Disponível em: http://www2.camara.sp.gov.br/Lei-Organica/Lei-Organica.pdf. Acesso:18 Jan. 2010.

Coligação Muda São Paulo, 2000. Programa de Governo. São Paulo.

Finatec, 2004. Descentralização e poder local: a experiência das subprefeituras no município de São Paulo. São Paulo: Hucitec.

Prefeitura Municipal de São Paulo, 1991a. Proposta de novo modelo de estrutura organizacional. São Paulo: Secretaria Especial da Reforma Administrativa.

,1991b. Nova territorialização. São Paulo: Secretaria das Administrações Regionais: Assessoria Técnica de Sistemas de Informática.

1992a. O poder em São Paulo: história da administração pública na cidade, 1554-1992. São Paulo: Cortez. 1992b. São Paulo: Crise e Mudança. São Paulo: Brasiliense.

2002. Subprefeituras - documentos sobre a descentralização político-administrativa do Município de São Paulo. São Paulo: Secretaria Municipal das Subprefeituras.

,2003. Orçamento Participativo - Ciclo Temático 2002. São Paulo: Coordenadoria do Orçamento Participativo.

2004. Sumário de Dados 2004. São Paulo: Secretaria de Governo Municipal.

. Lei n. 13 169, de 11 de julho de 2001. Dispõe sobre a reorganização parcial das estruturas organizacionais das Secretarias Municipais que especifica e dá outras providências. Diário Oficial da Cidade de São Paulo.

. Projeto de lei 546/2001. Dispõe sobre a criação de Subprefeituras no município de São Paulo e dá outras providências.

. Lei n. 13 399, de 17 de julho de 2002. Dispõe sobre a criação de Subprefeituras no município de São Paulo. Diário

Oficial da Cidade de São Paulo, São Paulo, 01 Ago. 2002.

. Lei n. 13 682, de 15 de dezembro de 2003. Dispõe sobre a estrutura organizacional das Subprefeituras. Diário Oficial da Cidade de São Paulo.

. Decreto n. 40 227, de 01 de janeiro de 2001. Altera denominação da Secretaria Municipal das Administrações Regionais. Diário Oficial da Cidade de São Paulo.

. Decreto n. 41 813, de 15 de março de 2002. Dispõe sobre a instituição do Governo Local no âmbito territorial. Diário Oficial da Cidade de São Paulo, São Paulo.

Decreto n. 42 561, de 30 de outubro de 2002. Dispõe sobre a coordenação da implantação das Subprefeituras. Diário Oficial da Cidade de São Paulo, São Paulo.

. Decreto n. 42 670, de 02 de dezembro de 2002. Dispõe sobre a transferência de instâncias decisórias da Secretaria Municipal das Subprefeituras para as Subprefeituras. Diário Oficial da Cidade de São Paulo, São Paulo.

. Decreto n. 42 771, de 03 de janeiro de 2003. Dispõe sobre a transferência da Secretaria Municipal de Saúde para as Subprefeituras Diário Oficial da Cidade de São Paulo, São Paulo.

. Decreto n. 42 772, de 03 de janeiro de 2003. Dispõe sobre a transferência da Secretaria Municipal de Educação para as Subprefeituras Diário Oficial da Cidade de São Paulo.

. Decreto n. 43 796, de 16 de setembro de 2003. Dispõe sobre a transferência da Secretaria Municipal de Abastecimento para as Subprefeituras Diário Oficial da Cidade de São Paulo, São Paulo.

. Decreto n. 43 799, de 16 de setembro de 2003. Dispõe sobre a transferência da Secretaria Municipal de Abastecimento para as Subprefeituras Diário Oficial da Cidade de São Paulo, São Paulo.

. Decreto n. 43 822, de 18 de setembro de 2003. Dispõe sobre providências da transferência da administração dos Centros Educacionais Unificados para as Subprefeituras Diário Oficial da Cidade de São Paulo, São Paulo.

. Decreto n. 44 418, de 26 de fevereiro de 2004. Dispõe sobre a transferência de parte das competências da Secretaria de Habitação e Desenvolvimento Urbano as Subprefeituras. Diário Oficial da Cidade de São Paulo, São Paulo.

SMSP/SGM/SGP, 2002. Dispõe sobre a estrutura organizacional das Subprefeituras. Portaria Intersecretarial n. 6, Diário Oficial da Cidade de São Paulo, São Paulo. 


\section{Abstract}

This research deals with the implementation of the Subprefectures in São Paulo city during the term of mayor Marta Suplicy (2001/2004). The article seeks to contribute for a lacking theme in the Brazilian political science: the intramunicipal decentralization and their effects in the administrative and political game. We perfomed a qualitative analisys using the case study method and the process tracing to identify the causal conditions that influenced in the administrative and political configuration of the Subprefectures. We discuss how the Subprefectures served to the government to consolidate its legislative support, despite of putting in second place the participatory democracy in the regions. We analyze how the government envisaged the resistence of municipal Secretaries fearful of losing power to the Subprefectures. The article discusses two hyphotheses. The fisrt, is that government backed the proposed project of Subprefectures before the opposition from municipal Secretaries, fed by the internal dispute in the PT, majoritary party, and their goals of power in these bodies. The decentralization was conditioned to the level of adhesion from the sectoral policies. The second one understands the the government abandoned the model of Subprefectures as cores of local power supported for social control, because these passed to serve to expand the political alliances in parlament, relegating the Participatory Budget to a secondary position. The hypotheses were conformed because the causal explanation suggested was evidenced in the empirical analysis. Administratively the limited scope of the Subprefectures had as core cause the fearful of the Secretaries of losing power to the regions. The decentralization depended how the Secretaties involved in this process. Politicaly, the Subprefectures were resources to the government to increase its coaltion support being this the causal explanation of the priority conferred by the government to the aldermen's logic.

KEYWORDS: subprefectures; decentralization; political coalitions; aldermen; social control.

License information: This is an open-access article distributed under the terms of the Creative Commons Attribution License (CC-BY-NC 4.0), which permits unrestricted use, distribution, and reproduction in any medium, provided the original work is properly cited. 